\title{
Assessing branched tetraether lipids as tracers of soil organic carbon transport through the Carminowe Creek catchment (southwest England)
}

\author{
Jingjing Guo ${ }^{1}$, Miriam Glendell ${ }^{2}$, Jeroen Meersmans ${ }^{3}$, Frédérique Kirkels ${ }^{1}$, Jack J. Middelburg ${ }^{1}$, and \\ Francien Peterse ${ }^{1}$ \\ ${ }^{1}$ Department of Earth Sciences, Utrecht University, 3584 CB Utrecht, the Netherlands \\ ${ }^{2}$ The James Hutton Institute, Craigiebuckler, Aberdeen, AB15 8QH, UK \\ ${ }^{3}$ TERRA Teaching and Research Centre, Gembloux Agro-Bio Tech, University of Liège, 5030 Gembloux, Belgium
}

Correspondence: Jingjing Guo (j.guo@uu.nl)

Received: 19 December 2019 - Discussion started: 11 March 2020

Revised: 14 May 2020 - Accepted: 25 May 2020 - Published: 24 June 2020

\begin{abstract}
Soils represent the largest reservoir of organic carbon (OC) on land. Upon mobilization, this $\mathrm{OC}$ is either returned to the atmosphere as carbon dioxide $\left(\mathrm{CO}_{2}\right)$ or transported and ultimately locked into (marine) sediments, where it will act as a long-term sink of atmospheric $\mathrm{CO}_{2}$. These fluxes of soil OC are, however, difficult to evaluate, mostly due to the lack of a soil-specific tracer. In this study, a suite of branched glycerol dialkyl glycerol tetraethers (brGDGTs), which are membrane lipids of soil bacteria, is tested as specific tracers for soil OC from source (soils under arable land, ley, grassland, and woodland) to sink (Loe Pool sediments) in a small catchment located in southwest England (i.e. Carminowe Creek draining into Loe Pool). The analysis of brGDGTs in catchment soils reveals that their distribution is not significantly different across different land use types $(p>0.05)$ and thus does not allow land-use-specific soil contributions to Loe Pool sediments to be traced. Furthermore, the significantly higher contribution of 6-methyl brGDGT isomers in creek sediments (isomerization ratio $(\mathrm{IR})=0.48 \pm 0.10$, mean \pm standard deviation (SD); $p<0.05)$ compared to that in catchment soils (IR $=0.28 \pm 0.11)$ indicates that the initial soil signal is substantially altered by brGDGT produced in situ. Similarly, the riverine brGDGT signal appears to be overwritten by lacustrine brGDGTs in the lake sedimentary record, indicated by remarkably lower methylation of branched tetraethers $\left(\mathrm{MBT}_{5 \mathrm{ME}}^{\prime}=0.46 \pm 0.02\right.$ in creek bed sediments and $0.38 \pm$ 0.01 in lake core sediments; $p<0.05$ ) and a higher degree
\end{abstract}

of cyclization ( $\mathrm{DC}=0.23 \pm 0.02$ in creek bed sediments and $0.32 \pm 0.08$ in lake core sediments). Thus, in this small catchment, brGDGTs do not allow us to trace soil OC transport. Nevertheless, the downcore changes in the degree of cyclization and the abundance of isoprenoid GDGTs produced by methanogens in the Loe Pool sediment do reflect local environmental conditions over the past 100 years and have recorded the eutrophication history of the lake.

\section{Introduction}

Globally, around $1500-2000 \mathrm{Pg}$ of carbon is stored in soils in the form of organic matter, which is about 2 times the amount of carbon in the atmosphere and 3 times the amount of carbon in vegetation (Janzen, 2004; Smith, 2008). Soil organic carbon (OC) plays an important role in the global carbon cycle, as subtle alterations in the soil OC reservoir may affect the concentration of atmospheric $\mathrm{CO}_{2}$ and thus influence climate change (Davidson and Janssens, 2006). Atmospheric $\mathrm{CO}_{2}$ that is fixed by plants through photosynthesis will be stored in the soil OC pool, part of which will be transferred to streams and rivers. Upon fluvial discharge, soil OC is buried and locked into the marine or lacustrine sediment, where it will act as a long-term carbon sink. However, instead of a passive pipeline in the carbon cycle, rivers actually represent a dynamic channel, where part of the soil OC is respired back to the atmosphere, and another part may be stored in river 
bed or lake sediments before reaching the ocean (Cole et al., 2007; Battin et al., 2009; Aufdenkampe et al., 2011). Hence, it is hard to determine the exact amount of soil OC that is transported to the ocean, as the dynamic processes that soil OC undergoes during transport, such as degradation and sequestration, are elusive. This is mostly due to the lack of a specific tracer to distinguish soil OC from the total pool of OC that is also comprised of plant-derived OC, aquatically produced OC, and fossil OC from rock erosion (Blair et al., 2004; Aufdenkampe et al., 2011).

To circumvent this problem, lipid biomarkers can be used to trace a specific part of the total OC pool in complex natural environmental systems (Brassell and Eglinton, 1986; Wakeham and Lee, 1993). For example, odd-numbered long-chain $n$-alkanes derived from epicuticular plant waxes are widely used to detect the contribution of terrestrial OC to riverdominated marine sediments (Eglinton and Hamilton, 1967; Hedges et al., 1997; Fernandes and Sicre, 2000; Glendell et al., 2018). Similarly, lignin, an abundant biopolymer in vascular plants (Hedges et al., 1997), has been used to trace OC transport along the terrestrial-aquatic continuum in, for example, the Mississippi River (Goñi et al., 1997; Bianchi et al., 2004), the Amazon River (Hedges et al., 1986, 2000; Feng et al., 2016), and Arctic rivers (Feng et al., 2013). However, these biomarkers are derived from vegetation, which, although land-derived, is not fully representative of soil OC. Thus, in order to specifically trace and quantify the pool of soil OC, another biomarker is needed.

Branched glycerol dialkyl glycerol tetraethers (brGDGTs; Fig. 1) are membrane-spanning tetraether lipids synthesized by heterotrophic bacteria that thrive in soils and peats all over the world (Weijers et al., 2006a, 2007a; Naafs et al., 2017). Although the exact producers of these lipids are still unknown, after the detection of a brGDGT and the presumed brGDGT precursor lipid iso-diabolic acid in Acidobacterial cultures (Sinninghe Damsté et al., 2011, 2014, 2018), it was assumed that members of this phylum are the main source organisms of brGDGTs in soils. However, a biological source outside the phylum of Acidobacteria cannot be excluded (Sinninghe Damsté et al., 2018). The occurrence and relative distribution of brGDGTs in a global set of modern surface soils showed that they can have 4 to 6 methyl groups attached to their alkyl backbone, where the degree of branching increases in soils from colder areas. Furthermore, brGDGTs respond to changes in soil $\mathrm{pH}$ by forming up to two cyclopentane moieties following internal cyclization, where a higher number of cyclopentane moieties corresponds to a higher soil pH (Weijers et al., 2007a). Initially, a combination of two proxies, the methylation of branched tetraethers (MBT) index and cyclization of branched tetraethers (CBT) index, was proposed as a proxy to reconstruct the mean air temperature (MAT) and pH of a soil (Weijers et al., 2007a; Peterse et al., 2012). After the identification of novel brGDGT isomers that possess a methyl group at the $\alpha$ and/or $\omega$ position 6 rather than at position 5 (Fig. 1) and the improvement of the chro- matography method used for brGDGT analysis, a modified temperature proxy, the $\mathrm{MBT}_{5 \mathrm{ME}}^{\prime}$ was developed (De Jonge et al., 2013, 2014b). Furthermore, the relative abundance of 6-methyl brGDGT isomers, quantified as the isomerization ratio (IR), appeared to also relate to soil $\mathrm{pH}$ (De Jonge et al., 2014b). Indeed, the analysis of brGDGTs in peat profiles and loess-paleosol sequences has resulted in long-term continental paleotemperature records for various areas, e.g. in deglacial central China (Peterse et al., 2011) and northeast China (Zheng et al., 2017), and western Europe during the early Eocene (Inglis et al., 2017).

These brGDGTs have not only been found in soils, but also in coastal marine sediments, where they have been used as the terrestrial end-member in the branched and isoprenoid tetraether (BIT) index that determines the relative contribution of fluvially supplied soil organic matter to marine sediments, where the latter is represented by amounts of the isoprenoid GDGT crenarchaeol (Hopmans et al., 2004). For example, the relative abundance of brGDGTs in a marine sediment core from the Bay of Biscay revealed the early re-activation of European rivers after the last deglaciation (Ménot et al., 2006). Furthermore, brGDGTs stored in continental margin sediments are assumed to represent an integrated climate signal of the nearby land and have been used as such to generate temperature records of deglacial tropical Africa (Weijers et al., 2007b) and Pliocene northwestern Europe (Dearing Crampton-Flood et al., 2018).

Recently, however, brGDGTs have also been found to be produced in aquatic systems such as coastal marine areas (Peterse et al., 2009; Sinninghe Damsté, 2016), rivers (Kim et al., 2012; Zell et al., 2013, 2014) and lakes (Sinninghe Damsté et al., 2009; Tierney and Russell, 2009; Loomis et al., 2011, 2014; Schoon et al., 2013; Weber et al., 2015, 2018), which complicates the interpretation of brGDGTbased proxy records. A contribution of in situ-produced brGDGTs in lakes or on the continental shelf may bias BIT index values towards a more terrestrial signal (e.g. Sinninghe Damsté et al., 2009; De Jonge et al., 2015). Aquatic production in coastal marine areas first became apparent upon comparison of brGDGTs in Svalbard fjord sediments and nearby soils. Whereas the brGDGT signal in the fjord sediments was dominated by compounds containing cyclopentane moieties, soils were characterized by brGDGTs without cyclization (Peterse et al., 2009). These substantially different brGDGT signatures in combination with the increasing concentration of brGDGTs towards the open ocean then pointed towards a contribution of in situ-produced brGDGTs to the fjord sediments. Similarly, brGDGT distributions in lake sediments were found to differ from those in soils surrounding the lake (Sinninghe Damsté et al., 2009; Tierney and Russell, 2009) and generated temperature estimates that severely underestimated actual MAT, mostly due to a high relative abundance of hexamethylated brGDGTs (e.g. Tierney et al., 2010; Loomis et al., 2014; Weber et al., 2015). Finally, the presence of brGDGTs with a polar headgroup 
Ia

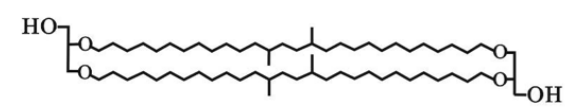

$\mathrm{Ib}$

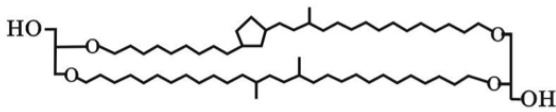

Ic

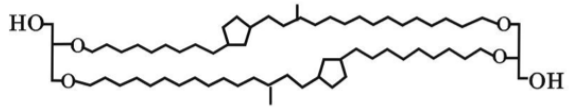

IIa

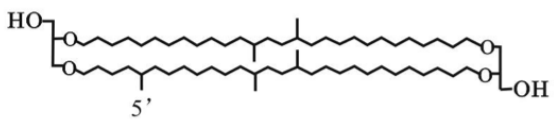

IIb
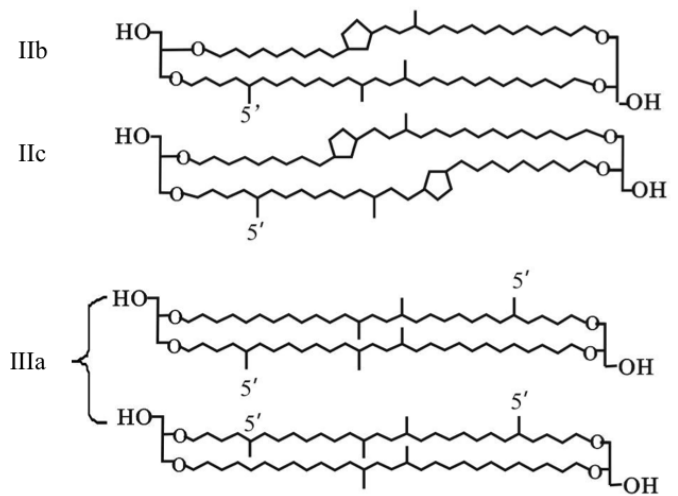

IIIb

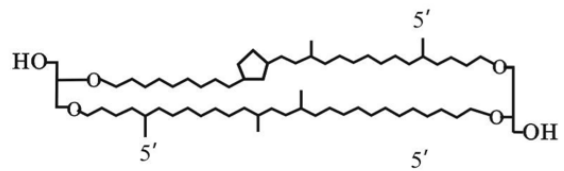

IIIc

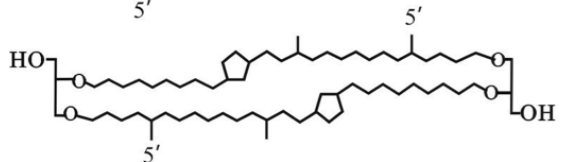

1050

1050

$[\mathrm{M}+\mathrm{H}]^{+}$

1022

1020

1018

1036

1034

1048

1046

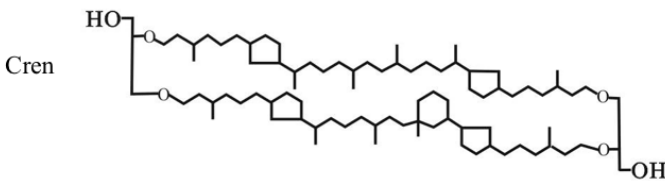

$[\mathrm{M}+\mathrm{H}]$

Cren'

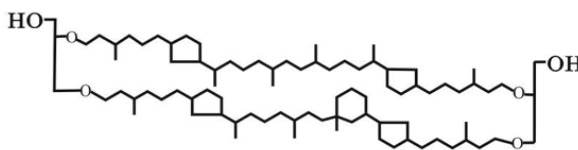

GDGT-0

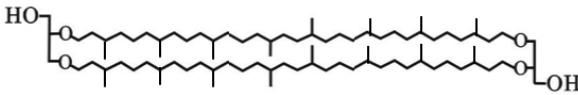

1302
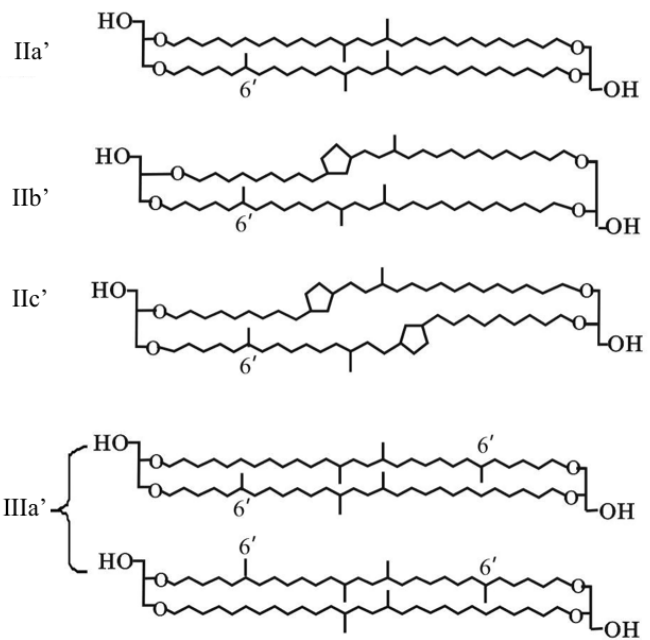

1050

IIIb

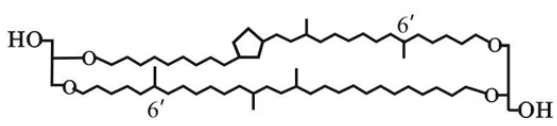

1048

III'

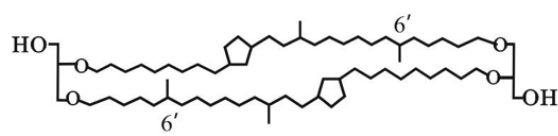

1046

Figure 1. Molecular structures of 5-methyl and 6-methyl branched GDGTs, GDGT-0, and crenarchaeol. The 6-methyl brGDGTs are represented by apostrophes. The structures of penta- and hexamethylated brGDGTs with cyclopentane moiety(ies) IIb' ${ }^{\prime}$ IIc' IIIb $^{\prime}$, and IIIc ${ }^{\prime}$ are tentative.

still attached in suspended particulate matter (SPM) of several large rivers (Zhang et al., 2012; Zell et al., 2013; De Jonge et al., 2014a) provided strong evidence for aquatic production, as these headgroups are thought to be lost within days after cell death (e.g. Harvey et al., 1986). Notably, these and subsequent studies proposed ways to recognize in situ production of brGDGTs in aquatic environments. For example, a high degree of cyclization is an indicator of brGDGT production in coastal marine zones (Peterse et al., 2009; Sinninghe Damsté, 2016), for which Sinninghe Damsté (2016) proposed that a weighted number of rings in tetramethylated brGDGTs, quantified as \#rings tetra $>0.7$ indicates a purely marine source of brGDGTs in continental margin sediments. In rivers, aquatic brGDGTs appear to be characterized by a relatively high contribution of 6-methyl brGDGT isomers and can be quantified using the IR (De Jonge et al., 2014a).

Here we test brGDGTs as tracers for soil OC in Carminowe Creek catchment, a small catchment in southwest England. Previously, an attempt was made to follow OC transport from soil (source) to Loe Pool, the final sink of this catchment, using a combination of stable isotopes of bulk soil $\mathrm{OC}$ and plant leaf wax $n$-alkanes as fingerprints for the different vegetation types present in the catchment (i.e. arable land, grassland, ley, and woodland) (Glendell et al., 2018). Although most land use types had a distinct $n$-alkane fingerprint, OC derived from arable land and temporary grassland (ley) could not be distinguished (Glendell et al., 2018). Hence, by assuming a primary soil source of the brGDGTs, 
their analysis in the same samples may contribute to tracing soil OC from different land use types during transport in Carminowe Creek. Moreover, changes in GDGT distributions in a $50 \mathrm{~cm}$ long sediment core from Loe Pool may be used to infer changes in soil OC transport dynamics in the catchment over the past century and potentially couple them to climate or anthropogenic activity related events in the catchment area.

\section{Methods}

\subsection{Study site and sampling}

An overview of the study area and sampling sites is given by Glendell et al. (2018). Briefly, the Carminowe Creek catchment is located in Cornwall in southwest England $\left(50^{\circ} 14^{\prime} \mathrm{N}\right.$, $5^{\circ} 16^{\prime} \mathrm{W}$ ), covers an area of around $4.8 \mathrm{~km}^{2}$ and varies in elevation from 0 to $80 \mathrm{~m}$ above sea level (a.s.l.; Fig. 2). It is divided into two subcatchments ("north" and "south"). The two streams converge around $100 \mathrm{~m}$ before their joint outlet and then flow into a natural freshwater lake, Loe Pool (50 ha), which is separated from the Atlantic Ocean by a natural shingle barrier. The mean annual temperature (MAT) and mean annual precipitation (MAP) in this area are approximately $11^{\circ} \mathrm{C}$ and $1000 \mathrm{~mm} \mathrm{yr}^{-1}$, respectively. The land use in this studied catchment is dominated by arable land and temporary grasslands (ley), which are under rotation. The steeper hillslopes are under permanent grassland, and riparian woodland covers the areas near the creek. For this study, 74 surface soil samples $(0-15 \mathrm{~cm})$ were collected along 14 hillslope transects, including 31 arable land sites, 14 permanent grassland sites, 24 temporary grassland (ley) sites, and 5 woodland sites (Fig. 2). Riverbed sediments were collected at three locations along each of the two tributaries (upstream, midstream, and downstream), and one more at the joint outlet. A $50 \mathrm{~cm}$ long sediment core was taken in the lake, about $150 \mathrm{~m}$ away from the joint outlet. The lake core has been dated by the activity of caesium-137 $\left({ }^{137} \mathrm{Cs}\right)$, and it covers the last 100 years (Glendell et al., 2018).

\subsection{Bulk soil properties}

Total carbon contents were reported by Glendell et al. (2018). Soil $\mathrm{pH}$ was measured in this study using a $\mathrm{pH}$ meter in a soil-to-water ratio of $1: 5(w: v)$ after shaking for $2 \mathrm{~h}$.

\subsection{GDGT extraction and analysis}

In total, 74 soil samples, 7 creek bed sediment samples, and 25 lake core sediment samples were analysed for GDGTs. First, 5-7 $\mathrm{g}$ of the soils or 3-5 $\mathrm{g}$ of the sediments were freeze dried and homogenized, after which they were extracted 3 times with dichloromethane (DCM)-MeOH $(9: 1, v / v)$ using an accelerated solvent extractor (ASE 350, Dionex ${ }^{\mathrm{TM}}$ ) at $100^{\circ} \mathrm{C}$ and $7.7 \times 10^{6} \mathrm{~Pa}$ to obtain a total lipid extract (TLE).
After addition of a known amount of $\mathrm{C}_{46}$ GDGT internal standard (Huguet et al., 2006), the TLEs were dried under a $\mathrm{N}_{2}$ stream and then separated into apolar and polar fractions by passing them over an activated $\mathrm{Al}_{2} \mathrm{O}_{3}$ column using hexane-DCM $(9: 1, v / v)$ and DCM-MeOH $(1: 1, v / v)$ respectively. The polar fraction, which contains the GDGTs, was evaporated to dryness under a gentle $\mathrm{N}_{2}$ stream. After this, the samples were prepared for further analysis by redissolving them in a hexane-isopropanol $(99: 1, v / v)$ mixture, and filtration through a $0.45 \mu \mathrm{m}$ polytetrafluoroethylene (PTFE) filter.

The GDGTs were analysed on an Agilent 1260 Infinity ultra-high-performance liquid chromatographer (UHPLC) coupled to an Agilent 6130 single quadrupole mass spectrometer (MS) with settings according to Hopmans et al. (2016). The GDGTs were separated over two silica Waters Acquity UPLC BEH Hilic columns $(1.7 \mu \mathrm{m}$, $2.1 \mathrm{~mm} \times 150 \mathrm{~mm}$ ) preceded by a guard column with the same packing. GDGTs were eluted isocratically at a flow rate of $0.2 \mathrm{~mL} \mathrm{~min}^{-1}$ using $82 \% A$ and $18 \% B$ for $25 \mathrm{~min}$, followed by a linear gradient to $70 \% A$ and $30 \% B$ for $25 \mathrm{~min}$, where $A=$ hexane and $B=$ hexane-isopropanol $(9: 1, v / v)$. Sample injection volumes were $10 \mu \mathrm{L}$. Ionization of the GDGTs was achieved by atmospheric pressure chemical ionization with the following source settings: gas temperature $200^{\circ} \mathrm{C}$, vaporizer temperature $400^{\circ} \mathrm{C}, \mathrm{N}_{2}$ flow $6 \mathrm{~L} \mathrm{~min}^{-1}$, capillary voltage $3500 \mathrm{~V}$, nebulizer pressure 25 psi and a corona current of $5.0 \mu \mathrm{A}$. By scanning the $[\mathrm{M}+\mathrm{H}]^{+}$ ions (protonated mass) in selected ion monitoring (SIM) mode, the target compounds were detected at $\mathrm{m} / \mathrm{z} 1302$ (GDGT-0), 1292 (crenarchaeol), 1050 (brGDGT-IIIa), 1048 (brGDGT-IIIb), 1046 (brGDGT-IIIc), 1036 (brGDGT-IIa), 1034 (brGDGT-IIb), 1032 (brGDGT-IIc), 1022 (brGDGTIa), 1020 (brGDGT-Ib), and 1018 (brGDGT-Ic), with $\mathrm{m} / z 744$ for the internal standard. Quantitation was achieved by peak area integration of the $[\mathrm{M}+\mathrm{H}]^{+}$ions in Chemstation software B.04.03.

\subsection{GDGT proxy calculations}

The roman numerals in the following equations refer to the molecular structures of GDGTs in Fig. 1. The ratios below were calculated based on the fractional abundances (indicated by using square brackets) of GDGTs. The BIT index was calculated according to Hopmans et al. (2004) and modified to also include 6-methyl brGDGTs:

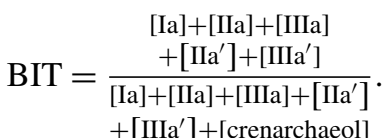

The degree of methylation $\left(\mathrm{MBT}_{5 \mathrm{ME}}^{\prime}\right)$ and relative abundances of tetra-, penta-, and hexamethylated brGDGTs were calculated following De Jonge et al. (2014b) and Sinninghe Damsté (2016): 


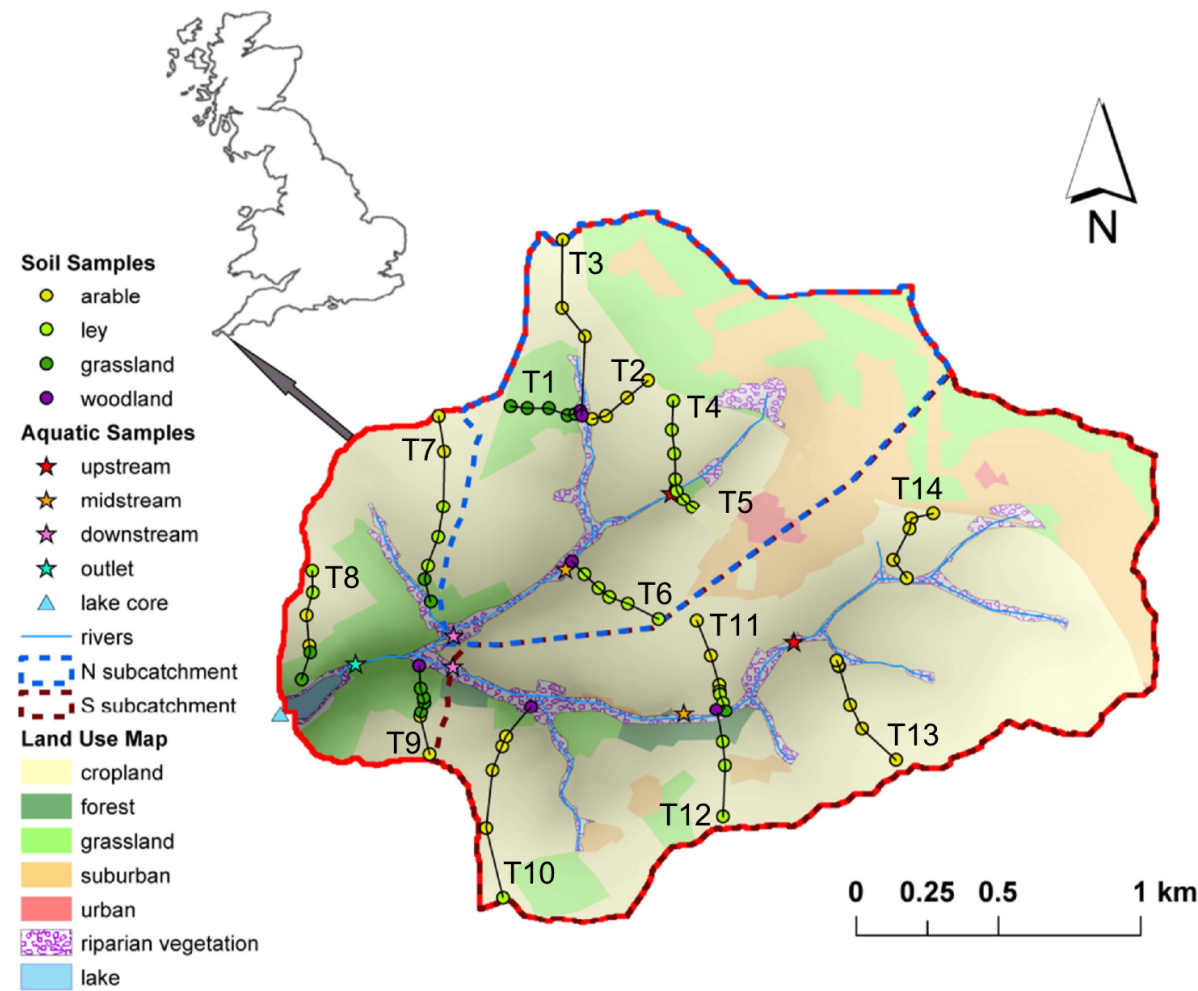

Figure 2. Map of the Carminowe Creek catchment in southwest England showing land use types, 14 soil transects (labelled T1-14), creek bed and lake core sediment sampling locations. The coloured circles and stars indicate soil samples under different land use types and creek bed sediments along the streams, respectively. Adjusted from Glendell et al. (2018).

$\mathrm{MBT}_{5 \mathrm{ME}}^{\prime}=\frac{[\mathrm{Ia}]+[\mathrm{Ib}]+[\mathrm{Ic}]}{\begin{array}{c}{[\mathrm{Ia}]+[\mathrm{Ib}]+[\mathrm{Ic}]+[\mathrm{IIa}]} \\ +[\mathrm{IIb}]+[\mathrm{IIc}]+[\mathrm{III}]\end{array}}$

$\%$ tetra $=\sum[$ tetramethylated brGDGTs $]$

$$
=[\mathrm{Ia}]+[\mathrm{Ib}]+[\mathrm{Ic}],
$$

$\%$ penta $=\sum[$ pentamethylated brGDGTs $]$

$$
=[\mathrm{IIa}]+[\mathrm{IIIb}]+[\mathrm{IIc}]+\left[\mathrm{IIa}^{\prime}\right]+\left[\mathrm{IIb}^{\prime}\right]+\left[\mathrm{IIc}^{\prime}\right],
$$

$\%$ hexa $=\sum[$ hexamethylated brGDGTs $]$

$$
\begin{aligned}
& =[\mathrm{III}]+[\mathrm{III} b]+[\mathrm{IIIc}]+\left[\mathrm{IIIa}^{\prime}\right]+\left[\mathrm{IIIb}^{\prime}\right] \\
& +\left[\mathrm{IIIc}^{\prime}\right] .
\end{aligned}
$$

Furthermore, the degree of cyclization (DC) was calculated according to Baxter et al. (2019):

$$
\mathrm{DC}=\frac{[\mathrm{Ib}]+2 \cdot[\mathrm{Ic}]+[\mathrm{IIb}]+\left[\mathrm{IIb}^{\prime}\right]}{[\mathrm{Ia}]+[\mathrm{Ib}]+[\mathrm{Ic}]+[\mathrm{IIa}]+\left[\mathrm{IIa}^{\prime}\right]+[\mathrm{IIb}]+\left[\mathrm{IIb}^{\prime}\right]} .
$$

The isomerization ratio (IR) is the ratio between penta- and hexamethylated 6-methyl brGDGTs and the total amount of both 5- and 6-methyl penta- and hexamethylated brGDGTs (De Jonge et al., 2014a):

$$
\begin{aligned}
& {\left[\mathrm{IIa}^{\prime}\right]+\left[\mathrm{IIb}^{\prime}\right]+\left[\mathrm{IIc}^{\prime}\right]} \\
& \mathrm{IR}=\frac{+\left[\mathrm{IIIa}^{\prime}\right]+\left[\mathrm{IIIb}^{\prime}\right]+\left[\mathrm{IIIc}^{\prime}\right]}{[\mathrm{IIa}]+\left[\mathrm{IIa}^{\prime}\right]+[\mathrm{IIb}]+\left[\mathrm{IIb}^{\prime}\right]+[\mathrm{IIc}]+\left[\mathrm{IIc}^{\prime}\right]} .
\end{aligned}
$$

\subsection{Statistical analysis and data visualization}

The statistical analysis and data visualization were undertaken in $\mathrm{R}$ software (version 3.5.2) (R Core Team, 2018). Differences in the concentration of brGDGTs and brGDGTbased proxies between different land use types (i.e. arable land, grassland, ley, and woodland), creek bed, and lake core sediments were examined by one-way nested ANOVA under a generalized linear model (GLM) followed by post hoc analysis (Tukey honest significant difference test) and were performed with the packages "car", "carData", and "agricolae". Differences were considered to be significant at a level of $p<0.05$. To show how close our sample mean is to the population mean, standard deviation is used (mean \pm SD). To examine whether brGDGT signatures could distinguish soil OC derived from different land use types, principal component analysis (PCA) was performed with package "FactoMineR" and "factoextra". The box plot and scatter plots were carried out with package "ggplot2". 


\section{Results}

\subsection{BrGDGTs in soils}

Most of the brGDGTs were present in all soils. Only brGDGT-IIIc and brGDGT-IIIc' were always below the detection limit (peak height $>3 \times$ baseline), and brGDGTIIc $^{\prime}$ was below the detection limit in 13 of the soils (three in arable land, four in grassland, and six in ley). The brGDGTs were dominated by pentamethylated (49.4 \pm $3.0 \%$, mean $\pm \mathrm{SD}$ ), followed by tetramethylated (39.7 \pm $4.9 \%)$ and then hexamethylated brGDGTs $(10.9 \pm 2.6 \%$; Table 1). The concentration of brGDGTs ranged between 0.1 and $1.7 \mu \mathrm{g} \mathrm{g}^{-1}$ soil, with an average of $0.2 \pm 0.1 \mu \mathrm{g} \mathrm{g}^{-1}$ soil in arable land, $0.6 \pm 0.4 \mu \mathrm{g} \mathrm{g}^{-1}$ soil in grassland, and $0.4 \pm 0.3 \mu \mathrm{g} \mathrm{g}^{-1}$ soil in ley (i.e. the temporary grassland). However, the concentration of brGDGTs in woodland was $3.0 \pm 1.0 \mu \mathrm{g} \mathrm{g}^{-1}$ soil, which was significantly higher than that in other land use types $\left(0.4 \pm 0.3 \mu \mathrm{g} \mathrm{g}^{-1}\right.$ soil; $p<0.05$; Fig. 3a). The C-normalized concentration of brGDGTs in catchment soils ranged between 2.8 and $49.8 \mu \mathrm{g} \mathrm{g}^{-1} \mathrm{C}, 8.1 \pm$ $3.6 \mu \mathrm{g} \mathrm{g}^{-1} \mathrm{C}$ in arable land, $11.2 \pm 6.7 \mu \mathrm{g} \mathrm{g}^{-1} \mathrm{C}$ in grassland, $10.5 \pm 4.8 \mu \mathrm{g} \mathrm{g}^{-1} \mathrm{C}$ in ley, and $37.6 \pm 11.0 \mu \mathrm{g} \mathrm{g}^{-1} \mathrm{C}$ in woodland (Fig. 3a; Table 1). The trend of the concentration of brGDGTs along the soil transects was not obvious.

BIT index values ranged from 0.57 to 1.00 among land use types (Fig. 3b), with an average value of $0.96 \pm 0.03$ in woodland, $0.90 \pm 0.12$ in ley, $0.88 \pm 0.14$ in grassland, and $0.83 \pm 0.09$ in arable land (without significant differences, $p>0.05$ ). However, the BIT values increased from hillslope to downslope along several transects in the north catchment, while the BIT values show no clear trends in the south catchment (Fig. A1a in Appendix A). The $\mathrm{MBT}_{5 \mathrm{ME}}^{\prime}$ ranged from 0.37 to 0.71 and was mostly similar between all land use types $(0.48 \pm 0.04 ; p>0.05$; Fig. $3 c$; Table 1$)$. The degree of cyclization between land use types was similar $(\mathrm{DC}=0.23 \pm 0.13$; Fig. 3d; Table $1 ; p>0.05$ ); likewise, the IR ranged from 0.10 to $0.60(0.28 \pm 0.01$ on average; Fig. 3e; Table $1 ; p>0.05$ ), without a clear trend along the soil transects. However, four transects in the north catchment have on average significantly higher IR values $(>0.36)$ than the other transects in the catchment $(0.24 \pm 0.09 ; p<0.05$; Fig. A1b). In general, the IR increases with increasing soil $\mathrm{pH}$ in the catchment $\left(r^{2}=0.36, p<0.001\right)$.

\subsection{BrGDGTs in creek bed sediments}

All brGDGT compounds were detected in creek bed sediments, except for in the site upstream from the north catchment, where brGDGT-IIIc ${ }^{\prime}$ was below the detection limit. The brGDGTs in creek bed sediments were dominated by pentamethylated brGDGTs $(45.0 \pm 0.7 \%)$, followed by tetramethylated brGDGTs $(30.1 \pm 4.5 \%)$ and hexamethylated brGDGTs $(24.9 \pm 4.7 \%)$ (Table 1$)$. The Cnormalized concentration of brGDGTs in creek bed sed-

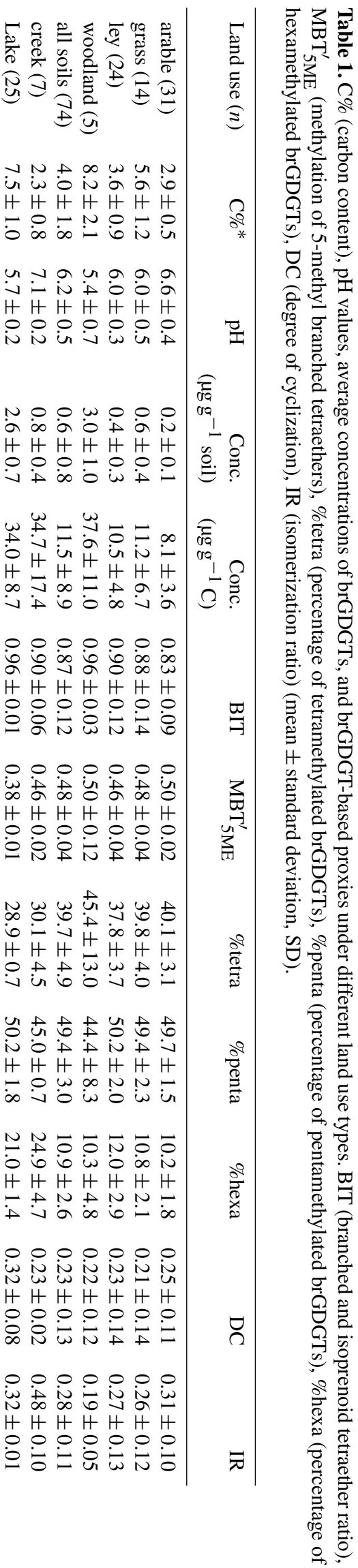

https://doi.org/10.5194/bg-17-3183-2020 

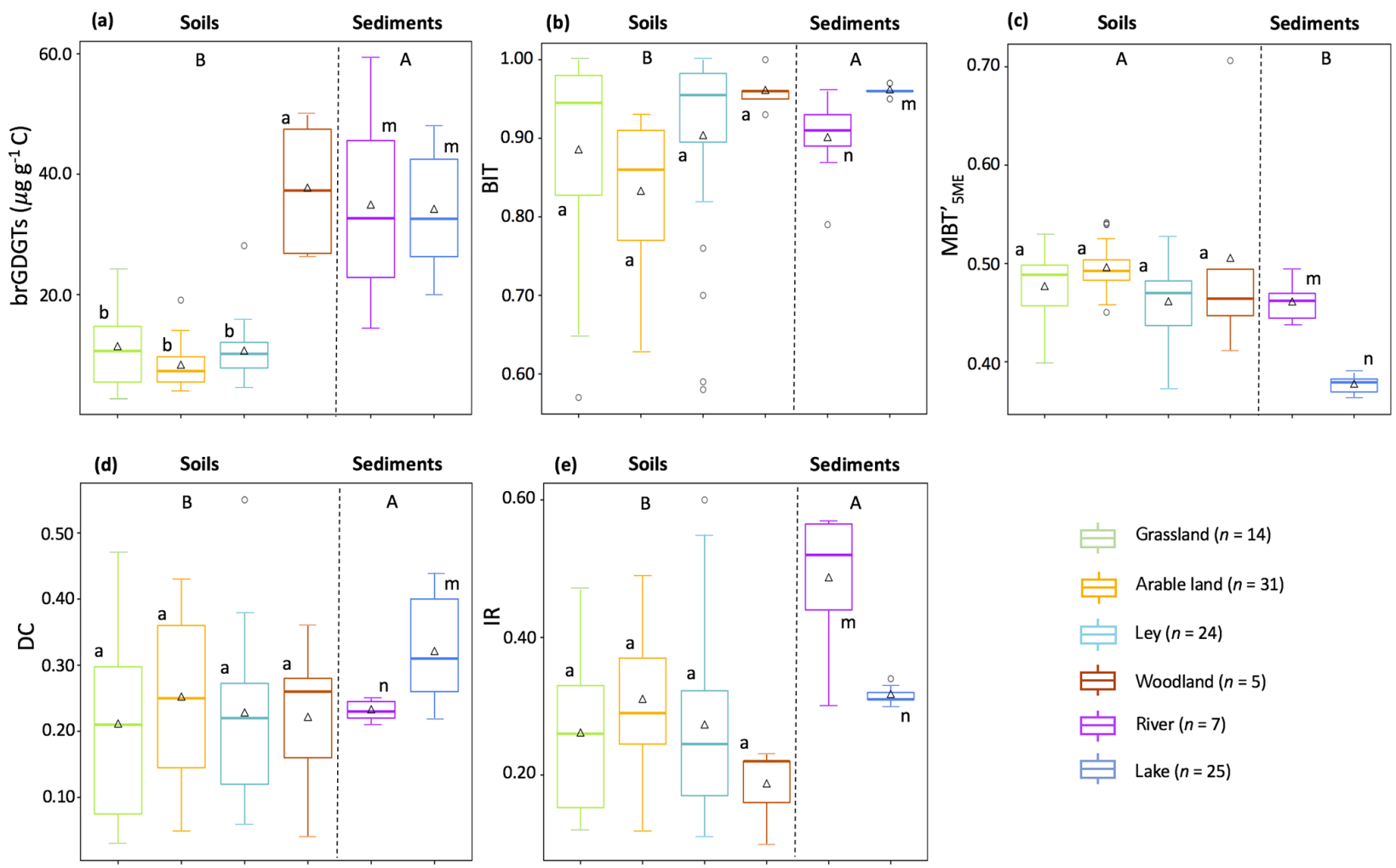

Figure 3. Box plots displaying (a) the C-normalized concentration of brGDGTs and brGDGT-based proxies, (b) BIT index (branched and isoprenoid tetraether ratio), (c) $\mathrm{MBT}_{5 \mathrm{ME}}^{\prime}$ (methylation of 5-methyl branched tetraethers), (d) DC (degree of cyclization), and (e) IR (isomerization ratio). The triangles represent the average values, the bold line indicates the median (50th percentile), the bottom and top of the box indicate first quartile (25th percentile) and third quartile (75th percentile) respectively, and whiskers cover the smallest and largest value within 1.5 times of the interquartile range (i.e. the distance between the top and bottom of the box). Any data points outside the whiskers are considered as outliers. Different letters indicate differences between samples: A and B for differences between catchment soils and aquatic sediments, $\mathrm{a}$ and $\mathrm{b}$ for soils under different vegetation types, and $\mathrm{m}$ and $\mathrm{n}$ for creek bed and lake core sediments $(p<0.05)$.

iments was $34.7 \pm 17.4 \mu \mathrm{gg}^{-1} \mathrm{C}$ on average (Fig. 3a; Table 1), where the concentration increased from 32.7 to $57.0 \mu \mathrm{g} \mathrm{g}{ }^{-1} \mathrm{C}$ downstream in the north catchment, and from 14.3 to $25.2 \mu \mathrm{g} \mathrm{g}^{-1} \mathrm{C}$ downstream in the south catchment, reaching a maximum value of $59.3 \mu \mathrm{g} \mathrm{g}^{-1} \mathrm{C}$ at the outlet (Fig. 5a). The concentration of brGDGTs in creek bed sediments was higher than that in soils under any land use types, except for woodland $\left(9.6 \pm 4.9 \mu \mathrm{g} \mathrm{g}^{-1} \mathrm{C}\right.$; Fig. 3a; Table 1).

The BIT values for creek sediments were on average $0.90 \pm 0.06$ (Fig. 3b; Table 1). The $\mathrm{MBT}_{5 \mathrm{ME}}^{\prime}$ was relatively constant between 0.44 and 0.49 , with an average of $0.46 \pm$ 0.02 . The DC ranged from 0.21 to 0.25 in the creek sediments with an average of $0.23 \pm 0.02$ (Fig. 3e; Table 1). The IR was relatively invariable with an average of $0.48 \pm 0.10$ (Fig. 3e; Table 1). The brGDGT-based proxies for creek bed sediments were similar to those for soils, except for the IR, which was higher than that in soils under any land use types $(0.28 \pm 0.11$; Fig. 3 ; Table 1$)$.

\subsection{BrGDGTs in the Loe Pool sediment core}

All brGDGTs were detected in the lake sediment core, except at $20 \mathrm{~cm}$ depth, where brGDGT-IIIc' was below the detection limit. The brGDGTs in the lake sediments were mainly dominated by pentamethylated brGDGTs $(50.2 \pm 1.8 \%)$, followed by tetramethylated brGDGTs $(28.9 \pm 0.7 \%)$ and hexamethylated brGDGTs $(21.0 \pm 1.4 \%$; Table 1$)$. The amount of brGDGTs in lake core sediments ranged from 19.9 to $48.0 \mathrm{\mu g} \mathrm{g}^{-1} \mathrm{C}$ (Fig. 3a; Table 1). The brGDGT concentration in the surface sediment $(0-2 \mathrm{~cm})$, of $37.7 \mu \mathrm{g} \mathrm{g}^{-1} \mathrm{C}$, which was about 1.6 times lower than that in the creek sediment at the outlet (Fig. 5a), increased to a maximum of $48.0 \mu \mathrm{g} \mathrm{g}^{-1} \mathrm{C}$ at around $11 \mathrm{~cm}$ depth and then decreased to a minimum of $19.9 \mu \mathrm{g} \mathrm{g}^{-1} \mathrm{C}$ at $23 \mathrm{~cm}$ depth (Fig. 6b). The concentration of GDGT- 0 ranged between $9.0 \mathrm{\mu g} \mathrm{g}^{-1} \mathrm{C}$ and $27.1 \mu \mathrm{g} \mathrm{g}^{-1} \mathrm{C}$ with an average of $17.4 \pm 6.0 \mu \mathrm{g} \mathrm{g}^{-1} \mathrm{C}$, and the concentration of crenarchaeol ranged from 0.6 to $1.4 \mu \mathrm{g} \mathrm{g}^{-1} \mathrm{C}$ with an average of $1.0 \pm 0.2 \mu \mathrm{g} \mathrm{g}^{-1} \mathrm{C}$ in the lake sediment core. In general, the concentration of brGDGTs in the lake core $\left(34.0 \pm 8.7 \mu \mathrm{g} \mathrm{g}^{-1} \mathrm{C}\right.$; Table 1$)$ was similar to 
that in rivers and in woodlands, while it was significantly higher than the brGDGTs in soils except for the woodland $\left(9.6 \pm 4.9 \mu \mathrm{g} \mathrm{g}^{-1} \mathrm{C} ; p<0.05\right.$; Fig. 3a; Table 1).

The BIT values for the lake sediment core were rather uniform, varying between 0.95 and 0.97 (Fig. 3b). Similarly, the values of $\mathrm{MBT}_{5 \mathrm{ME}}^{\prime}$ along the lake core ranged only between 0.36 and 0.39 . The $\mathrm{MBT}_{5 \mathrm{ME}}^{\prime}$ of 0.37 for the lake surface sediment was significantly lower than that in creek bed sediments $(0.46 \pm 0.02 ; p<0.05$; Figs. 3c; $5 b)$. Conversely, the DC in the lake surface sediment was 0.39 , which was significantly higher than that in creek bed sediments $(0.23 \pm 0.02$; $p<0.05$; Figs. 3d; 5b). The average value of DC for the lake core sediments was $0.32 \pm 0.08$. The DC increased from the surface to a maximum value $(0.44)$ at around $10 \mathrm{~cm}$ depth and then decreased with slight fluctuations to 0.22 at $43 \mathrm{~cm}$ depth (Fig. 6c). The IR was constant downcore $(0.32 \pm 0.01$ on average; Fig. 3e; Table 1) and was significantly lower than that in creek bed sediments $(p<0.05$; Fig. 3e).

\section{Discussion}

\subsection{Spatial variation of brGDGT signals in catchment soils}

Spatial variations in the relative distribution of brGDGTs in all catchment soils were first evaluated by performing principal component analysis (PCA) using the fractional abundances of the 13 major brGDGTs detected. The first two principal components (PCs) explain $65.2 \%$ of the variance in the dataset. PC1 describes $49.5 \%$ of the variance and separates acyclic brGDGT-Ia and brGDGT-IIa from all the other brGDGTs (Fig. 4a). In line with this observation, PC1 has a strong positive relationship with the degree of cyclization of brGDGTs in the soils $\left(r^{2}=0.97\right.$; Fig. $\left.4 c\right)$. PC2 describes another $15.7 \%$ of the variance and separates tetramethylated brGDGTs as well as most of the 6-methyl brGDGTs from the majority of the 5-methyl penta- and hexamethylated brGDGTs. As a result, PC2 is negatively correlated with $\mathrm{MBT}_{5 \mathrm{ME}}^{\prime}\left(r^{2}=0.49\right.$; Fig. $\left.4 \mathrm{~d}\right)$ as well as the IR $\left(r^{2}=0.58\right.$; Fig. 4e) in soils. Despite the clear relation of the first two PCs with the degree of cyclization and the degree of methylation, respectively, the position of the soils in the PCA diagram reveals that different land use types are largely overlapping (Fig. 4b). Indeed, the brGDGT proxies for different land use types are not significantly different ( $p>0.05$; Fig. 3), making it difficult to distinguish the provenance of soil OC solely based on brGDGT signatures.

Indeed, previous work has also shown that brGDGT distributions are not primarily affected by land use. For example, brGDGTs in soils along an altitudinal transect in the Ethiopian highlands revealed that brGDGTs mainly reflect the decrease in temperature with increasing elevation, regardless of drastic changes in land use along the transect (Jaeschke et al., 2018). However, other studies report that vegetation cover does exert a great influence on brGDGT signatures in soils from Minnesota and Ohio, USA (Weijers et al., 2011); around Lake Rotsee, Switzerland (Naeher et al., 2014); in the Tibetan Plateau (Liang et al., 2019); and paddy and upland soils from subtropical (China and Italy) and tropical (Indonesia, Philippines and Vietnam) areas (MuellerNiggemann et al., 2016). The explanations for the similar distribution of brGDGTs under different land use types in the Carminowe Creek catchment could be the rotation and ploughing in land use in combination with the turnover time of brGDGTs. Although the soil bacterial community composition is generally different across distinct land use types (Fierer and Jackson, 2006; Steenwerth et al., 2003), the regular rotation (generally less than 5 years) of arable land and temporary grassland (ley) in the catchment (Glendell et al., 2018) may create a mixed bacterial community under all vegetation types. Beyond vegetation, regular ploughing as applied across the Carminowe catchment soils (arable land and ley) is recognized to have a more dominant, long-lasting effect on microbial communities (Drenovsky et al., 2010). Moreover, brGDGTs in terrestrial environments have a relatively long turnover time (ca. 18 years in soils, Weijers et al., 2010; and up to 40 years in peat, Huguet et al., 2017), especially when compared to the cropland rotation time. Taken together, these factors may contribute to the relatively similar brGDGT signal in all soils in the Carminowe catchment, further limiting the variation in brGDGT signals in catchment soils.

Some spatial trends are visible in spite of the overall comparable brGDGT signals across the catchment (Fig. A1), which may be explained by variations in other environmental factors than land use or vegetation. Mean air temperature and soil $\mathrm{pH}$ have been shown to be the main factors controlling the distribution of brGDGTs in soils worldwide (Weijers et al., 2007a; Peterse et al., 2012; De Jonge et al., 2014b). However, in the small (ca. $4.8 \mathrm{~km}^{2}$ ) Carminowe Creek catchment, the annual mean air temperature is practically the same for all soils. Similarly, the range in soil $\mathrm{pH}$ is relatively small among different land use types (from $5.4 \pm 0.3$ in woodland to $6.6 \pm 0.1$ in arable land; Table 1), which makes it difficult to separate brGDGT signals based on these parameters. Additionally, the soil water content (SWC) has been shown to affect the distribution and abundance of brGDGTs in soils, either directly by changing the microbial community or indirectly by altering soil temperature, soil $\mathrm{pH}$, or soil oxygen content (Dirghangi et al., 2013; Menges et al., 2014; Dang et al., 2016). The SWC is positively correlated with the abundance of brGDGTs in soils from the QinghaiTibetan Plateau (Wang et al., 2013), as well as in soils along an aridity transect in the USA (Dirghangi et al., 2013). Moreover, the degree of methylation of 6-methylated brGDGTs is sensitive to the SWC, especially in semi-arid and arid regions (Dang et al., 2016). Although MAP is also the same for the whole catchment, the subtle altitudinal differences in this small creek catchment (i.e. $0-80 \mathrm{~m}$ a.s.l.) may result in 

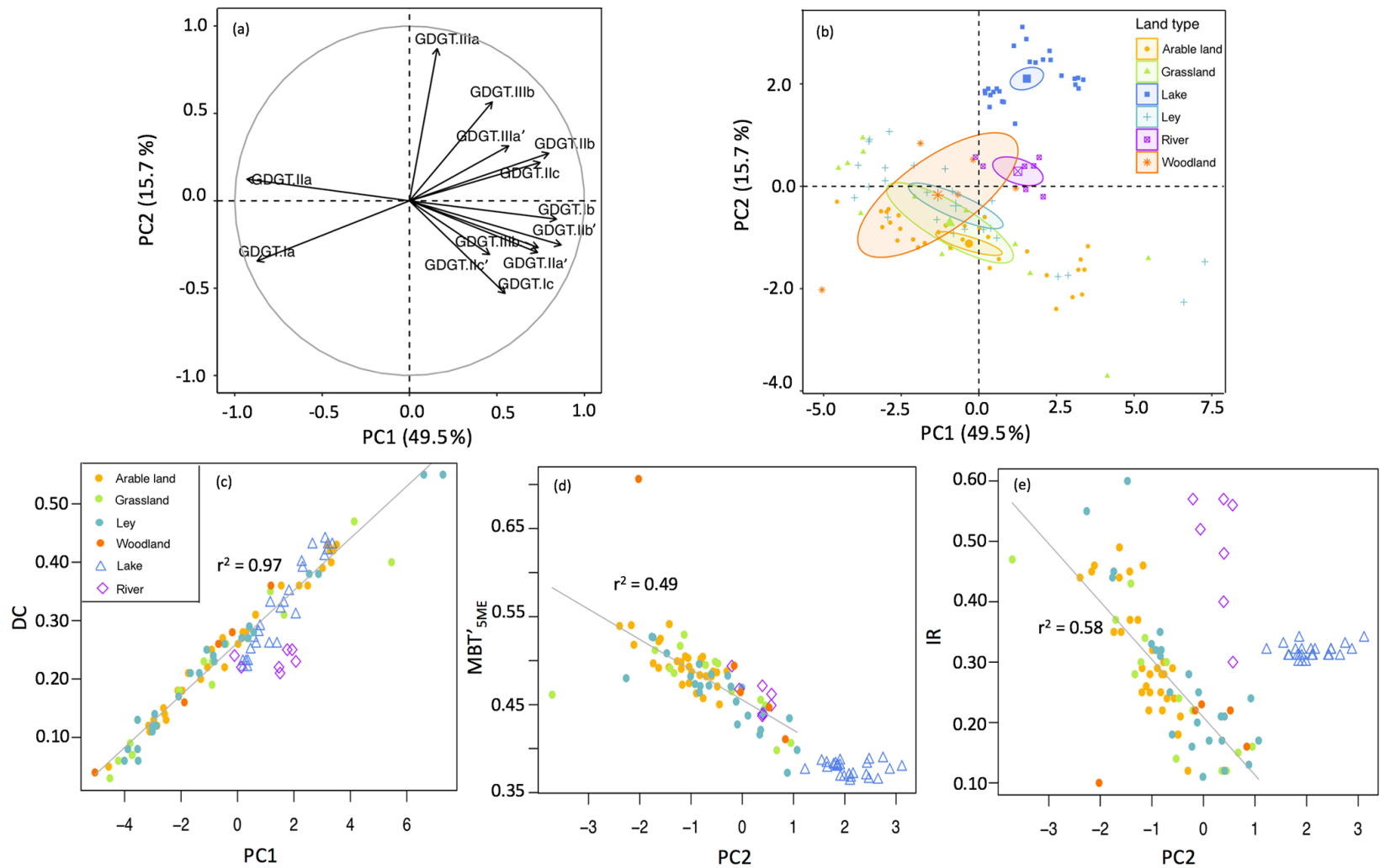

Figure 4. PCA based on the relative abundances of 13 major brGDGTs. Panel (a) shows the distribution of 13 brGDGTs (brGDGT-IIIc and brGDGT-IIIc' are excluded as they are below the detection limit) along the first two PCs, roman numerals and letters represent the compounds shown in Fig. 1. Panel (b) shows sampling site loading scores on the first two PCs and $95 \%$ confidence interval ellipses surrounding the mean point of different groups of land use: arable land $(n=31)$, grassland $(n=14)$, ley $(n=24)$, woodland $(n=5)$, creek $(n=7)$, and lake $(n=25)$. Panel (c) shows cross plots between PC1 and DC (degree of cyclization). Panels (d) and (e) show cross plots of PC2 with MBT ${ }_{5 \mathrm{ME}}$ (methylation of 5-methyl branched tetraethers) and IR (isomerization ratio) respectively. The linear correlation was calculated excluding creek and lake sediments.

an increase in SWC from hilltop to downslope. This would introduce just enough variability in SWC to explain some of the trends in brGDGT signals along hillslope transects. In the north catchment, the BIT index values gradually increase from the presumably better aerated soils at the hilltops towards the wetter soils closer to the creek (Fig. A1a). The increase is $>0.3$ for Transects 1 and 8 , but Transects 2, 3, and 7 also show an increase in BIT values downslope, albeit to a smaller degree $(0.17,0.19$, and 0.04 , respectively; Table A1 in Appendix A). The change in BIT index values is driven by both an increase in the amount of brGDGTs and a slight decrease in crenarchaeol concentrations with the presumed increase in SWC downslope, similar to previous findings (Dirghangi et al., 2013; Wang et al., 2013; Menges et al., 2014). The trend in BIT is likely enhanced by the (minor) change in soil $\mathrm{pH}$ along Transects 1 and 8 (from 6.2 to 6.1 along Transect 1 and from 6.6 to 5.7 along Transect 8), which may influence the BIT index as a result of the generally positive relation of crenarchaeol concentrations and a negative relation of brGDGT concentrations with increasing soil pH (Weijers et al., 2006b; Peterse et al., 2010). Never- theless, these trends in the BIT index are visible in five of the transects and only occur in the north part of the catchment.

Interestingly, the IR is also significantly higher in soils along four transects in the north catchment (all $>0.36$ on average for Transects 1,2, 7, and 8) compared to the average IR value for the rest of the transects in the entire catchment $(0.24 \pm 0.09 ; p<0.05)$. The majority of the sites with higher IR are in cropland, except for those in Transect 1, which is under grassland (Fig. A1b). Although a relative increase in 6-methyl brGDGTs has been linked to higher soil $\mathrm{pH}$ in the global soil dataset (De Jonge et al., 2014b), this relation is not so strong in the soils from the Carminowe creek catchment $\left(r^{2}=0.36, p<0.001\right)$, likely due to the relatively minor range and variation in soil $\mathrm{pH}$ (from $5.4 \pm 0.3$ to $6.6 \pm 0.1$ ). Nevertheless, the soils with high IR values in the north catchment also have $\mathrm{pH}$ values $>6.0$ with an average value of $6.6 \pm 0.1$. 


\subsection{Tracing brGDGTs from soils to creek bed sediments}

Based on the similar brGDGT signatures for soils under different land use types, these compounds cannot be used to trace back the exact source of the soil OC after mobilization and transport throughout the catchment. However, the concentration and general soil signature of the brGDGTs can be compared with those in creek bed sediments to trace the transfer of OC from the soils into the creeks. The Cnormalized concentration of brGDGTs in the creek sediments is higher than that in most of the soils $(34.7 \pm 17.4$ and $9.6 \pm 4.9 \mu \mathrm{g} \mathrm{g}^{-1} \mathrm{C}$ respectively), except for those in the woodland soils at the riverbanks $\left(37.6 \pm 11.0 \mu \mathrm{g} \mathrm{g}^{-1} \mathrm{C}\right.$; Table 1). Thus, purely based on the concentration, this suggests that brGDGTs in the creek would be primarily derived from the woodland, which also appeared to be the main source of $n$-alkanes in creek bed sediments (Glendell et al., 2018). However, when looking at the relative distribution of the brGDGTs, the percentage of hexamethylated brGDGTs in creek sediments is higher than that in soils $(24.9 \pm 1.8 \%$ and $10.9 \pm 0.3 \%$, respectively), whereas the percentage of tetramethylated brGDGTs is lower than that in soils ( $30.1 \pm 1.7 \%$ and $39.7 \pm 0.6 \%$, respectively; Table 1$)$. Furthermore, brGDGTs in creek sediments have a significantly higher IR (i.e. $0.48 \pm 0.04$ ) than soils under any of the land use types $(0.28 \pm 0.01$ on average in the catchment; $p<0.05$; Fig. 3e; Table 1). This is clearly reflected in the PCA, which separates the creek sediments from both the soils and lake sediments on PC2 that is associated with the IR (Fig. 4e). The higher IR in the creek bed sediments can be explained by a contribution of aquatically (i.e. in situ) produced 6-methyl brGDGTs. Similar contributions of 6-methyl brGDGTs, and thus higher IR, were also observed in suspended particulate matter from the Yenisei River (De Jonge et al., 2014a), and upstream of the Iron Gates in the Danube River, where the higher IR was coupled to in-river production facilitated by the lower flow velocity and decreased turbidity of the river water (Freymond et al., 2017). Hence, the significantly higher IR in combination with the higher Cnormalized concentrations of brGDGTs in the Carminowe creek sediments suggests that the brGDGT signal is mainly aquatic.

In an attempt to further prove the riverine in situ production of brGDGTs, we roughly estimate the minimum amount of 6-methyl brGDGTs that needs to be produced in the creek in order to reach the higher IR. We hereby assume that the brGDGTs derived from woodland soils are completely transferred into the creek without any degradation. Thus, the concentration of 6-methyl brGDGTs in the creek sediments [6$\left.\mathrm{me}_{\text {creek }}\right]$ resembles the sum of the average concentration of 6methyl brGDGTs in woodland soils [6-me woodland $_{\text {and those }}$

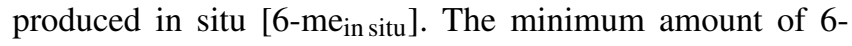
methyl brGDGTs produced in situ can then be calculated using the brGDGT-concentration-weighted IR for creek sed- iments $\left(\mathrm{IR}_{\text {creek }}=0.47\right)$ and the following equation (Eq. 8).

$$
\begin{aligned}
\mathrm{IR}_{\text {creek }} & =\frac{\left[6-\mathrm{me}_{\text {creek }}\right]}{\left[5-\mathrm{me}_{\text {creek }}\right]+\left[6-\mathrm{me}_{\text {creek }}\right]} \\
& =\frac{\left[6-\mathrm{me}_{\text {woodland }}\right]+\left[6-\mathrm{me}_{\text {in situ }}\right]}{\left[5-\mathrm{me}_{\text {creek }}\right]+\left[6-\mathrm{me}_{\text {woodland }}\right]+\left[6-\mathrm{me}_{\text {in situ }}\right]}
\end{aligned}
$$

Solving this equation results in a minimum amount of $7.4 \mu \mathrm{g} \mathrm{g}^{-1} \mathrm{C}$ 6-methyl brGDGTs that needs to be additionally produced in the creek to reach the higher IR. This accounts for $65 \%$ of the total amount of 6-methyl brGDGTs in the creek bed sediment that we measured. Considering a mixture of all soils rather than only woodland as the source of soil-derived brGDGTs in the creek results in the in situ production of $9.3 \mu \mathrm{g} \mathrm{g}^{-1} \mathrm{C}$ 6-methyl brGDGTs, corresponding to $81 \%$ of the 6-methyl brGDGT pool in the creek bed sediments. This implies that the initial soil brGDGT signal is rapidly overprinted by a riverine in situ signal upon entering the creek. Only the IR for the downstream site in the northern creek approaches that of the adjacent soil ( $I R=0.30$ in the creek bed sediment and $0.38 \pm 0.07$ for Transect 7 ; Fig. A1b) and may be explained by its use as arable land (Fig. 5a), which involves regular ploughing and subsequent soil mobilization and implies a temporary, local overprint.

The absence of a clearly recognizable soil brGDGT signal in the creek bed sediments may be further explained by the relatively limited input of soil material into the creek. So far, river systems that have been shown to transport a soilderived brGDGT signal are either characterized by a distinct rainy season (e.g. the Congo River, Weijers et al., 2007b; Hemingway et al., 2017; or the Amazon River, Kim et al., 2012), or have experienced a recent episode of extreme rainfall (e.g. the Danube River, $>100 \mathrm{~mm}$ in $3 \mathrm{~d}$ causing a 100year flood event, Freymond et al., 2017; or the Rhône River, with heavy rainfall during sampling; Kim et al., 2015). The Carminowe creek area does not have a clear rainy season and is further characterized by its limited relief. Hence, the relatively minor input of soil-derived brGDGTs seems to be easily overprinted by riverine in situ production. Alternatively, the soil-derived brGDGTs could be preferentially degraded in an aquatic environment as a result of the priming effect (Bianchi, 2011), which would lead to a signature that is dominated by brGDGTs that are produced in situ.

\subsection{Sources of brGDGTs in the sediments of Loe Pool}

In theory, rivers would transport soil-derived OC together with any aquatic OC produced along the way. Once discharged, in this case into a lake, the OC would settle and then be buried into the sediments where it would act as a longterm sink of OC. However, the soil brGDGT signal cannot be recognized in the sediments from Loe Pool since it is already lost upon entering Carminowe creek. Indeed, the PCA of the relative distributions of brGDGTs indicates that lake sediments plot completely separately from both the soils and creek sediments, mostly due to a higher relative abundance 
(a) Concentration

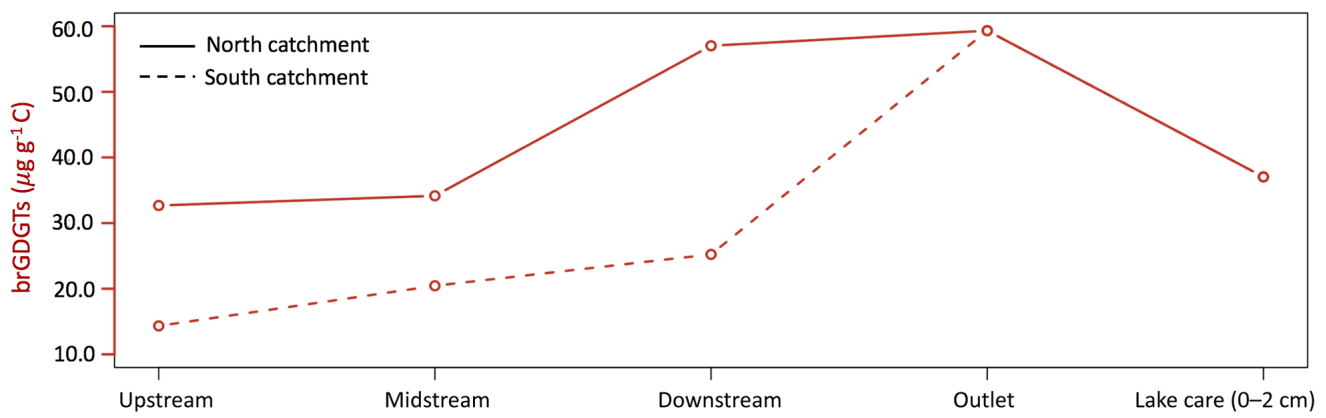

(b) $\mathrm{MBT}^{\prime}{ }_{5 \mathrm{ME}} \& \mathrm{DC}$

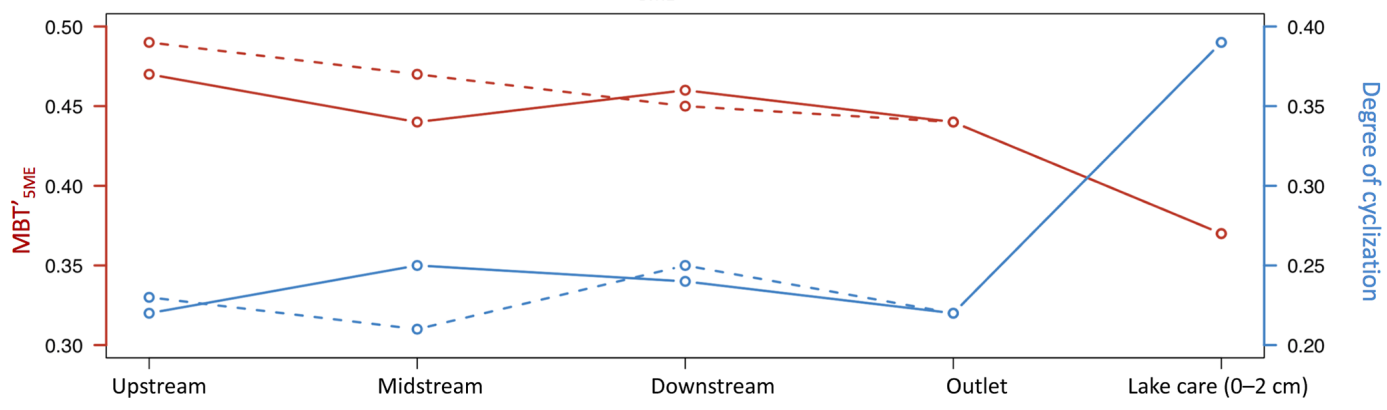

Figure 5. Spatial variability of (a) C-normalized concentration of brGDGTs and (b) $\mathrm{MBT}_{5 \mathrm{ME}}^{\prime}$ (methylation of 5-methyl branched tetraethers) and DC (degree of cyclization) in the downstream direction of both substreams in the Carminowe Creek catchment.

of GDGT-IIIa (Fig. 4a, b). As a result, the $\mathrm{MBT}_{5 \mathrm{ME}}^{\prime}$ is significantly lower in Loe Pool sediments $(0.38 \pm 0.00)$ compared to in the creek bed sediments $(0.46 \pm 0.01 ; p<0.05)$ and soils $(0.48 \pm 0.01 ; p<0.05$; Fig. $5 b$; Table 1$)$. Furthermore, the DC is significantly higher in lake sediments than in both soil and creek bed sediments $(0.32 \pm 0.02,0.23 \pm 0.01$, and $0.23 \pm 0.01$, respectively; $p<0.05$; Fig. 3d; Table 1). The distinct brGDGT signature of the lake sediments suggests that brGDGTs in the lake are again significantly altered compared to those in the soils and creek sediments. This implies that the riverine brGDGT signal is either replaced or overwritten in the lake.

Lacustrine in situ production of brGDGTs has been reported in other studies (Sinninghe Damsté et al., 2009; Tierney and Russell, 2009; Buckles et al., 2014; Loomis et al., 2011, 2014; Weber et al., 2015, 2018; Miller et al., 2018). However, there are no generally recognized indicators (yet) to identify lacustrine brGDGT production, although several studies reported a "cold bias" while attempting to reconstruct the mean air temperature (MAT) based on brGDGTs in lake sediments using a soil-based transfer function (Tierney et al., 2010). In a study on East African lakes, this cold bias was linked to a large in situ contribution of brGDGTIIIa (Tierney et al., 2010), similar to in Loe Pool. However, the East African lake dataset was generated using the "old" chromatography method that does not separate 5-methyl and 6-methyl brGDGTs. A recent study that has re-analysed the East African lake dataset indicates that the presumed contribution of GDGT-IIIa mainly consists of brGDGTIIIa' $^{\prime}$ (Russell et al., 2018), which is less prominent in Loe Pool. Although the identity of the brGDGT-producer(s) in lakes still remains elusive, a recent study from the stratified Lake Lugano (Switzerland) showed that the majority of the brGDGTs are produced in the lower, anoxic part of the water column rather than in the sediment (Weber et al., 2018). Furthermore, the combination of brGDGT analysis with molecular biological methods revealed that brGDGTs appeared to be produced by multiple groups of bacteria thriving under different redox regimes in this stratified lake. Specifically, brGDGT-IIIa occurred in the entire water column and continuously increased with depth, whereas brGDGT-IIIa' was mainly produced in the upper, oxygenated part of water column (Weber et al., 2018). Extrapolating the ecological niches of brGDGT production in Lake Lugano to Loe Pool we can speculate that brGDGT-IIIa, which is dominating the brGDGT signal in the Loe Pool sediments, is mostly produced in the lake during summer, when the eutrophic state of the lake may seasonally cause the anoxic conditions favourable for its (i.e. brGDGT-IIIa) production. However, our dataset does not allow us to further pinpoint the time and depth of lacustrine brGDGT production or to determine whether brGDGTs are solely produced in the water column of Loe Pool or also in the lake sediment. 

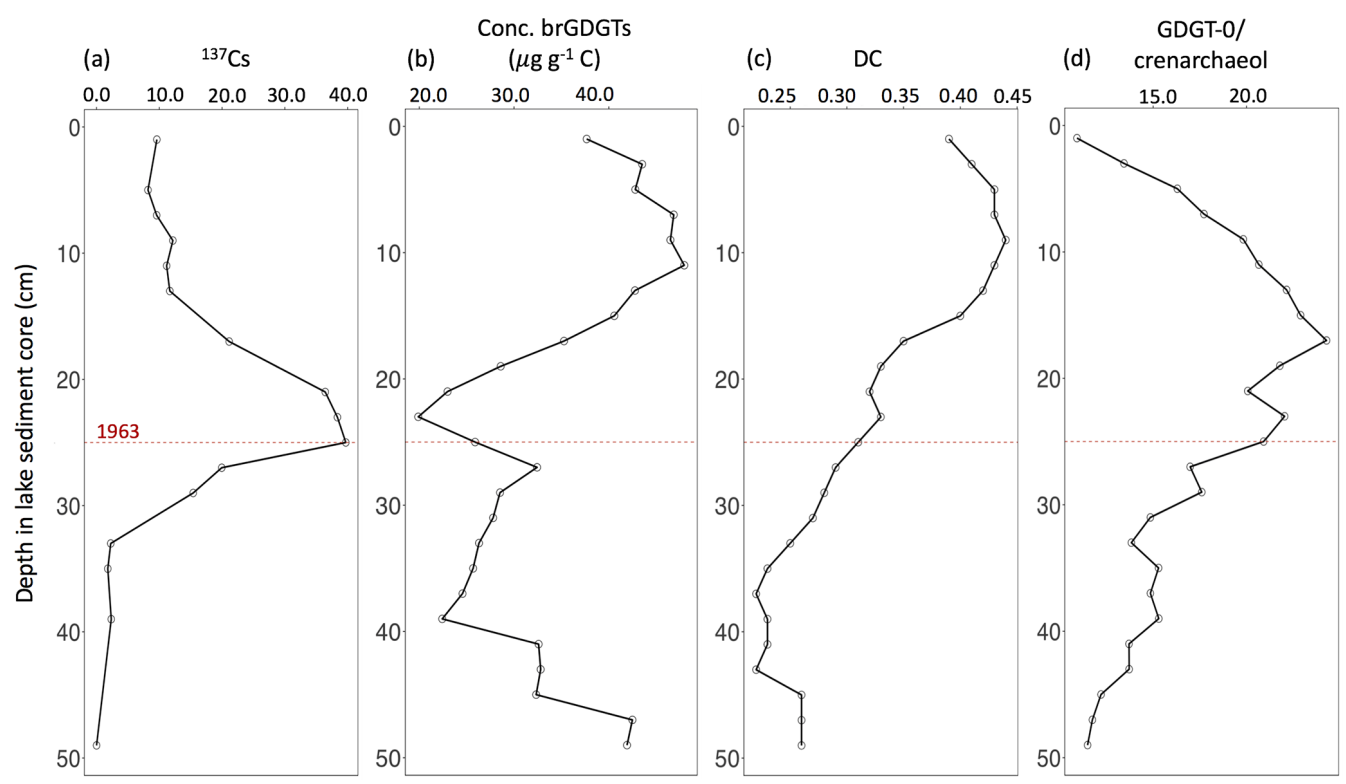

Figure 6. Lake sediment core profiles of (a) ${ }^{137} \mathrm{Cs}$ to date, (b) C-normalized concentration of brGDGTs, (c) DC (degree of cyclization) and (d) ratio between GDGT-0 and crenarchaeol. The red dashed line indicates the year of 1963 .

\subsection{Reconstructing local environmental changes based on GDGTs in Loe Pool lake sediments}

Downcore variations in the brGDGT distribution of Loe Pool sediments may provide information on past environmental changes in the catchment, in spite of the lacustrine in situ production in Loe Pool. The $50 \mathrm{~cm}$ deep sediment core covers about the last 100 years based on ${ }^{137}$ Cs activity (Glendell et al., 2018). The peak activity, correlated with bomb testing in the 1960s, was detected at $26 \mathrm{~cm}$ depth (Fig. 6a), which can thus be linked to 1963 (Glendell et al., 2018).

The C-normalized concentration of brGDGTs starts to increase at around $23 \mathrm{~cm}$, reaching a maximum concentration of $48.0 \mu \mathrm{g} \mathrm{g}^{-1} \mathrm{C}$ at $11 \mathrm{~cm}$ depth (Fig. 6b). The increased brGDGT concentrations coincide with an increase in the degree of cyclization (Fig. 6c), which generally responds to a change in $\mathrm{pH}$, where more cyclopentane moieties correspond to a higher pH (Weijers et al., 2007a; Schoon et al., 2013). According to historical records, agriculture and anthropogenic perturbations such as mining and urban pollution intensified in the 1960s ( $\sim 26 \mathrm{~cm}$ depth), which increased the input of soil and nutrients into Loe Pool (Coard et al., 1983) and resulted in eutrophication (i.e. blooms of cyanobacteria and algae) since at least $1986(\sim 23 \mathrm{~cm}$ depth $)$ (O'Sullivan, 1992; Flory and Hawley, 1994). Earlier studies have also recognized an increased use of farmyard manures and septic tanks at this time in the nitrogen isotopic composition of the lake sediments and have detected higher inputs of terrestrial organic material resulting from intensified farming practices and a higher erosion rate during the 1960 s to 1980 s based on ratios of aquatically and terrestrially derived plant waxes (Glendell et al., 2018). Thus, the high brGDGT concentrations and DC in the sediments likely reflect the eutrophic conditions of the lake resulting from the increased nutrient input to the lake (Coard et al., 1983). The DC then recorded the increase in lake water $\mathrm{pH}$ associated with eutrophication, whereas brGDGT concentrations express increased aquatic production. Due to remediation measures taken by the local government in $1996(\sim 12 \mathrm{~cm}$ depth), the eutrophication has reduced over the past 20 years (Glendell et al., 2018). The partial recovery of the lake has likely resulted in a return to lower lake water $\mathrm{pH}$, as manifested in the decrease in the DC from $\sim 10 \mathrm{~cm}$ depth upwards (Fig. 6c).

The process of eutrophication and subsequent recovery can also be recognized in the ratio between GDGT- 0 and crenarchaeol, which are isoprenoidal GDGTs produced by Archaea. Crenarchaeol is produced by ammonia oxidizing Thaumarchaeota (Sinninghe Damsté et al., 2002) in aquatic environments (Schouten et al., 2000; Powers et al., 2004) and to a lesser extent also in soils (Weijers et al., 2006a), whereas GDGT-0 is a membrane lipid that occurs in all major groups of Archaea but is indicative of methanogens and thus anaerobic conditions, with a typical ratio of GDGT-0 to crenarchaeol of $>2$ (Blaga et al., 2009). The ratio of GDGT-0 to crenarchaeol in the sediments of Loe Pool is $>2$ throughout the entire core, and ranges between 10.9 and 24.3, indicating that at least the bottom waters of the lake have been (seasonally) anoxic over the past 100 years (Fig. 6d), although the isoGDGTs may potentially be produced in deeper sediments. The ratio reaches its maximum at $16 \mathrm{~cm}$ depth, suggesting that eutrophic conditions and bottom water anoxia were most severe around this time. The recovery of the lake 
after the remediation measures is again reflected in the return to pre-1960 values at $\sim 10 \mathrm{~cm}$ depth (Fig. 6d).

\section{Conclusions}

In this study, brGDGTs were tested as a tracer for the transport of soil OC from different vegetation and land use types from source (soil) to sink (Loe Pool) in the Carminowe Creek catchment with the aim of reconstructing the provenance of the soil OC in Loe Pool sediments over time. Unfortunately, brGDGT signatures in the catchment soils are not distinct for land use types, indicating that other environmental parameters have a larger influence on the distribution of brGDGTs in these soils. Although temperature and precipitation can be considered equal for all soils due to the small size of the catchment, changes in BIT index values and the relative contribution of 6-methyl brGDGTs along a part of the hilltop transects indicate that SWC may exert a control on brGDGT signals, assuming that SWC increases downslope. The regular rotation of cropland in this catchment and the relative long turnover time of brGDGTs in soils could be another reason to explain the limited spatial variation in brGDGT signals.

Comparison of the soil-derived brGDGT signals to that of creek bed sediments reveals that the soil brGDGT signal is almost completely overprinted by aquatically produced brGDGTs, indicated by a substantially higher fractional abundance of 6-methyl brGDGTs in the creek. Upon discharge into the lake, the creek brGDGT signal is replaced by and/or mixed with a lacustrine in situ-produced brGDGT signal, which is characterized by a relatively higher DC and lower $\mathrm{MBT}_{5 \mathrm{ME}}^{\prime}$, as well as a specifically high fractional abundance of brGDGT-IIIa. Despite regular ploughing of the land, the absence of a profound rainy season and limited relief likely limits the degree of soil mobilization necessary to transfer the soil-derived brGDGT signal to the lake sediments in the modern system. Still, downcore variations in GDGT distributions in the sediments of Loe Pool do reflect local environmental conditions over the past 100 years. The degree of cyclization of brGDGTs as well as the ratio of isoprenoidal GDGT- 0 and crenarchaeol produced by Archaea trace the historical record of lake eutrophication induced by increased nutrient input from intensified agricultural activity in the catchment during the 1960 s to 1980 s, and its recovery after measures taken by the owner since 1996 . Our study shows that GDGTs in sedimentary archives are good recorders of past environmental and land management (e.g. agricultural intensification, increased fertilizer use) change, although the ability of brGDGTs to trace soil OC along a soil-aquatic continuum requires a higher degree of soil mobilization. 


\section{Appendix A}

Table A1. BIT values along 14 transects (Tx indicates the transect number, and Sx indicates the sample point, where 1 represents the hilltop and subsequent numbers are further downslope). Transects with a clear increase in BIT from hilltop to downslope are indicated in bold $(>0.3)$ or italic $(>0.1)$.

\begin{tabular}{|c|c|c|c|c|c|c|c|c|c|c|c|c|c|c|c|}
\hline & \multirow[t]{2}{*}{ BIT } & \multicolumn{8}{|c|}{ North catchment } & \multicolumn{6}{|c|}{ South catchment } \\
\hline & & T1 & $T 2$ & $T 3$ & $\mathrm{~T} 4$ & T5 & T6 & $T 7$ & T8 & T9 & $\mathrm{T} 10$ & $\mathrm{~T} 11$ & $\mathrm{~T} 12$ & $\mathrm{~T} 13$ & $\mathrm{~T} 14$ \\
\hline Hilltop & $\mathrm{S} 1$ & 0.65 & 0.66 & 0.77 & 0.97 & 0.99 & 0.97 & 0.77 & 0.58 & 0.92 & 0.92 & 0.84 & 0.95 & 0.84 & 0.86 \\
\hline 4 & $\mathrm{~S} 2$ & 0.57 & 0.66 & 0.86 & 0.99 & 0.99 & 0.93 & 0.65 & 0.59 & 0.91 & 0.63 & - & - & 0.73 & 0.88 \\
\hline & S3 & 0.73 & 0.77 & 0.87 & 1.00 & 1.00 & 0.94 & 0.82 & 0.80 & 0.98 & 0.90 & 0.92 & 0.98 & 0.91 & 0.88 \\
\hline & $\mathrm{S} 4$ & 0.88 & 0.83 & 0.96 & 0.99 & - & 0.96 & 0.70 & 0.85 & 1.00 & 0.92 & 0.72 & 0.98 & 0.92 & 0.86 \\
\hline & S5 & 0.95 & - & - & - & - & 0.97 & 0.76 & 0.98 & 1.00 & 0.91 & 0.91 & 1.00 & 0.91 & 0.93 \\
\hline & S6 & - & - & - & - & - & 0.96 & 0.94 & 0.97 & 1.00 & 0.93 & 0.85 & - & 0.90 & - \\
\hline & S7 & - & - & - & - & - & - & 0.81 & - & 0.95 & - & 0.92 & - & - & - \\
\hline Downslope & S8 & - & - & - & - & - & - & - & - & - & - & 0.92 & - & - & - \\
\hline
\end{tabular}
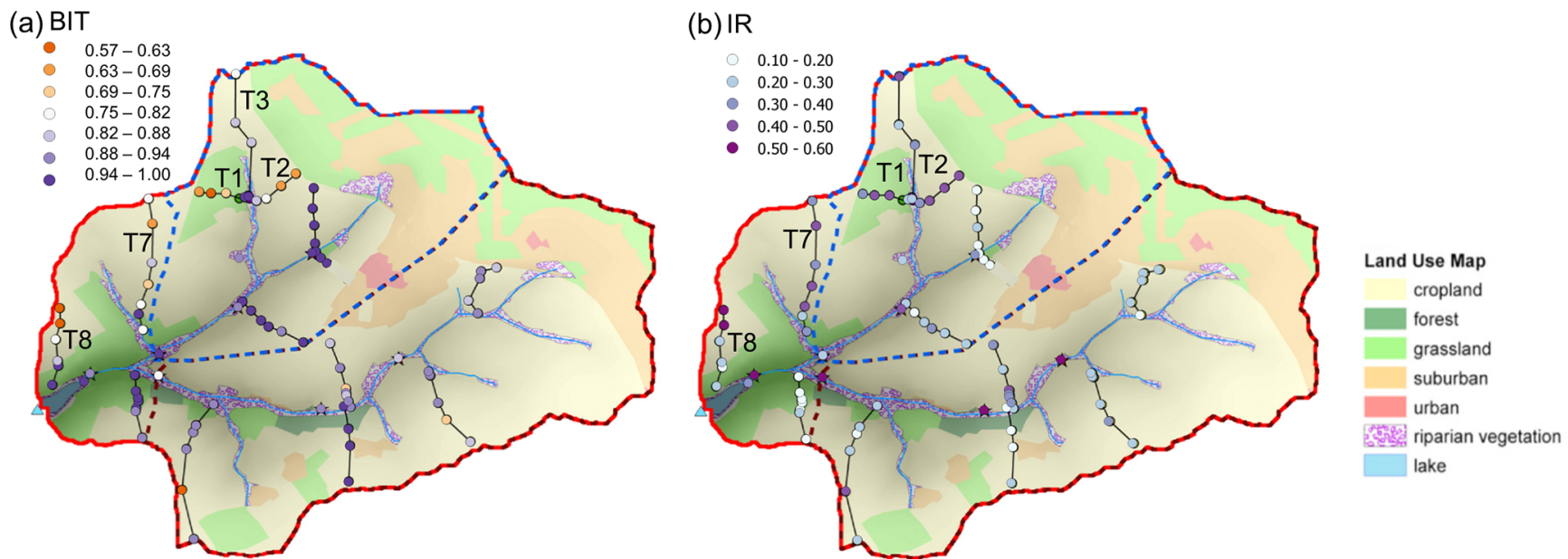

Figure A1. Spatial variability of the (a) BIT (branched and isoprenoid tetraether ratio) and (b) IR (isomerization ratio) along 14 soil transects in the Carminowe Creek catchment. The coloured circles show the concentrations and proxy values. T $x$ indicates soil transects discussed in the text. The background colours indicate different land use types. Adjusted from Glendell et al. (2018). 
Data availability. All data are available in the Supplement or at https://doi.org/10.1594/PANGAEA.918523 (Guo et al., 2020).

Supplement. The supplement related to this article is available online at: https://doi.org/10.5194/bg-17-3183-2020-supplement.

Author contributions. JM, FK, and FP designed the study. MG and JM collected the sample material. JG conducted the biomarker analysis and interpreted the data under supervision of FP and JJM. JG and FP wrote the paper with input from all co-authors.

Competing interests. The authors declare that they have no conflict of interest.

Acknowledgements. Desmond Eefting and Klaas Nierop (UU) are acknowledged for technical support. Robert Sparkes, the two anonymous reviewers and associate editor Anja Engel are thanked for their comments, which helped to improve this paper.

Financial support. This research has been supported by the NWO (Veni grant no. 863.13.016 and Vidi grant no. 192.074).

Review statement. This paper was edited by Anja Engel and reviewed by Robert Sparkes and two anonymous referees.

\section{References}

Aufdenkampe, A. K., Mayorga, E., Raymond, P. A., Melack, J. M., Doney, S. C., Alin, S. R., Aalto, R. E., and Yoo, K.: Riverine coupling of biogeochemical cycles between land, oceans, and atmosphere, Front. Ecol. Environ., 9, 53-60, https://doi.org/10.1890/100014, 2011.

Battin, T. J., Luyssaert, S., Kaplan, L. A., Aufdenkampe, A. K., Richter, A., and Tranvik, L. J.: The boundless carbon cycle, Nat. Geosci., 2, 598-600, https://doi.org/10.1038/ngeo618, 2009.

Baxter, A. J., Hopmans, E. C., and Russell, J. M.: ScienceDirect Bacterial GMGTs in East African lake sediments?: Their potential as palaeotemperature indicators, Geochim. Cosmochim. Ac., 259, 155-169, https://doi.org/10.1016/j.gca.2019.05.039, 2019.

Bianchi, T. S.: The role of terrestrially derived organic carbon in the coastal ocean: A changing paradigm and the priming effect, P. Natl. Acad. Sci. USA, 108, 19473-19481, https://doi.org/10.1073/pnas.1017982108, 2011.

Bianchi, T. S., Filley, T., Dria, K., and Hatcher, P. G.: Temporal variability in sources of dissolved organic carbon in the lower Mississippi River, Geochim. Cosmochim. Ac., 68, 959967, https://doi.org/10.1016/j.gca.2003.07.011, 2004.

Blaga, C. I., Reichart, G. J., Heiri, O., and Sinninghe Damsté, J. S.: Tetraether membrane lipid distributions in water-column particulate matter and sediments: A study of 47 European lakes along a north-south transect, J. Paleolimnol., 41, 523-540, https://doi.org/10.1007/s10933-008-9242-2, 2009.

Blair, N. E., Leithold, E. L., and Aller, R. C.: From bedrock to burial: the evolution of particulate organic carbon across coupled watershed-continental margin systems, Mar. Chem., 92, 141156, https://doi.org/10.1016/j.marchem.2004.06.023, 2004.

Brassell, S. C. and Eglinton, G.: Molecular geochemical indicators in sediments, in: Organic Marine Geochemistry ACS Symposium Series 305, edited by: Sohn, M. L., 10-32, American Chemical Society, Washington, 1986.

Buckles, L. K., Weijers, J. W. H., Tran, X.-M., Waldron, S., and Sinninghe Damsté, J. S.: Provenance of tetraether membrane lipids in a large temperate lake (Loch Lomond, UK): implications for glycerol dialkyl glycerol tetraether (GDGT)based palaeothermometry, Biogeosciences, 11, 5539-5563, https://doi.org/10.5194/bg-11-5539-2014, 2014.

Coard, M. A., Cousen, S. M., Cuttler, A. H., Dean, H. J., Dearing, J. A., Eglinton, T. I., Greaves, A. M., Lacey, K. P., O’Sullivan, P. E., Pickering, D. A., Rhead, M. M., Rodwell, J. K., and Simola, H.: Paleolimnological studies of annually-laminated sediments in Loe Pool, Cornwall, U.K., Hydrobiologia, 103, 185191, https://doi.org/10.1007/BF00028450, 1983.

Cole, J. J., Prairie, Y. T., Caraco, N. F., McDowell, W. H., Tranvik, L. J., Striegl, R. G., Duarte, C. M., Kortelainen, P., Downing, J. A., Middelburg, J. J., and Melack, J.: Plumbing the global carbon cycle: Integrating inland waters into the terrestrial carbon budget, Ecosystems, 10, 171-184, https://doi.org/10.1007/s10021006-9013-8, 2007.

Dang, X., Yang, H., Naafs, B. D. A., Pancost, R. D., and Xie, S.: Evidence of moisture control on the methylation of branched glycerol dialkyl glycerol tetraethers in semiarid and arid soils, Geochim. Cosmochim. Ac., 189, 24-36, https://doi.org/10.1016/j.gca.2016.06.004, 2016.

Davidson, E. A. and Janssens, I. A.: Temperature sensitivity of soil carbon decomposition and feedbacks to climate change, Nature, 440, 165-173, https://doi.org/10.1038/nature04514, 2006.

Dearing Crampton-Flood, E., Peterse, F., Munsterman, D., and Sinninghe Damsté, J. S.: Using tetraether lipids archived in North Sea Basin sediments to extract North Western European Pliocene continental air temperatures, Earth Planet. Sc. Lett., 490, 193205, https://doi.org/10.1016/j.epsl.2018.03.030, 2018.

De Jonge, C., Hopmans, E. C., Stadnitskaia, A., Rijpstra, W. I. C., Hofland, R., Tegelaar, E., and Sinninghe Damsté, J. S.: Identification of novel penta- and hexamethylated branched glycerol dialkyl glycerol tetraethers in peat using HPLCMS2, GC-MS and GC-SMB-MS, Org. Geochem., 54, 78-82, https://doi.org/10.1016/j.orggeochem.2012.10.004, 2013.

De Jonge, C., Stadnitskaia, A., Hopmans, E. C., Cherkashov, G., Fedotov, A., and Sinninghe Damsté, J. S.: In situ produced branched glycerol dialkyl glycerol tetraethers in suspended particulate matter from the Yenisei River, Eastern Siberia, Geochim. Cosmochim. Ac., 125, 476-491, https://doi.org/10.1016/j.gca.2013.10.031, 2014a.

De Jonge, C., Hopmans, E. C., Zell, C. I., Kim, J.-H., Schouten, S., and Sinninghe Damsté, J. S.: Occurrence and abundance of 6-methyl branched glycerol dialkyl glycerol tetraethers in soils: Implications for palaeoclimate reconstruction, Geochim. Cosmochim. Ac., 141, 97-112, https://doi.org/10.1016/j.gca.2014.06.013, 2014b. 
De Jonge, C., Stadnitskaia, A., Hopmans, E. C., Cherkashov, G., Fedotov, A., Streletskaya, I. D., Vasiliev, A. A., and Sinninghe Damsté, J. S.: Drastic changes in the distribution of branched tetraether lipids in suspended matter and sediments from the Yenisei River and Kara Sea (Siberia): Implications for the use of brGDGT-based proxies in coastal marine sediments, Geochim. Cosmochim. Ac., 165, 200-225, https://doi.org/10.1016/j.gca.2015.05.044, 2015.

Dirghangi, S. S., Pagani, M., Hren, M. T., and Tipple, B. J.: Distribution of glycerol dialkyl glycerol tetraethers in soils from two environmental transects in the USA, Org. Geochem., 59, 49-60, https://doi.org/10.1016/j.orggeochem.2013.03.009, 2013.

Drenovsky, R. E., Steenwerth, K. L., Jackson, L. E., and Scow, K. M.: Land use and climatic factors structure regional patterns in soil microbial communities, Global Ecol. Biogeogr., 19, 27-39, https://doi.org/10.1111/j.1466-8238.2009.00486.x, 2010.

Eglinton, G. and Hamilton, R. J.: Leaf Epicuticular Waxes, Science, 156, 1322-1335, https://doi.org/10.1126/science.156.3780.1322, 1967.

Feng, X., Vonk, J. E., van Dongen, B. E., Gustafsson, O., Semiletov, I. P., Dudarev, O. V., Wang, Z., Montlucon, D. B., Wacker, L., and Eglinton, T. I.: Differential mobilization of terrestrial carbon pools in Eurasian Arctic river basins, P. Natl. Acad. Sci. USA, 110, 14168-14173, https://doi.org/10.1073/pnas.1307031110, 2013.

Feng, X., Feakins, S. J., Liu, Z., Ponton, C., Wang, R. Z., Karkabi, E., Galy, V., Berelson, W. M., Nottingham, A. T., Meir, P., and West, A. J.: Source to sink: Evolution of lignin composition in the Madre de Dios River system with connection to the Amazon basin and offshore, J. Geophys. Res.-Biogeo., 121, 1316-1338, https://doi.org/10.1002/2016JG003323, 2016.

Fernandes, M. B. and Sicre, M. A.: The importance of terrestrial organic carbon inputs on Kara Sea shelves as revealed by nalkanes, OC and $\delta^{13} \mathrm{C}$ values, Org. Geochem., 31, 363-374, https://doi.org/10.1016/S0146-6380(00)00006-1, 2000.

Fierer, N. and Jackson, R. B.: The diversity and biogeography of soil bacterial communities, P. Natl. Acad. Sci. USA, 103, 62631, https://doi.org/10.1073/pnas.0507535103, 2006.

Flory, J. E. and Hawley, G. R. W.: A hydrodictyon reticulatum bloom at loe pool, cornwall, Eur. J. Phycol., 29, 17-20, https://doi.org/10.1080/09670269400650431, 1994.

Freymond, C. V., Peterse, F., Fischer, L. V., Filip, F., Giosan, L., and Eglinton, T. I.: Branched GDGT signals in fluvial sediments of the Danube River basin: Method comparison and longitudinal evolution, Org. Geochem., 103, 88-96, https://doi.org/10.1016/j.orggeochem.2016.11.002, 2017.

Glendell, M., Jones, R., Dungait, J. A. J., Meusburger, K., Schwendel, A. C., Barclay, R., Barker, S., Haley, S., Quine, T. A., and Meersmans, J.: Tracing of particulate organic C sources across the terrestrial-aquatic continuum, a case study at the catchment scale (Carminowe Creek, southwest England), Sci. Total Environ., 616-617, 1077-1088, https://doi.org/10.1016/j.scitotenv.2017.10.211, 2018.

Goñi, M. A., Ruttenberg, K. C., and Eglinton, T. I.: Sources and contribution of terrigenous organic carbon to surface sediments in the Gulf of Mexico, Nature, 389, 275-278, https://doi.org/10.1038/38477, 1997.
Guo, J., Glendell, M., Meersmans, J., Kirkels, F. M. S. A., Middelburg, J. J., and Peterse, F.: Branched tetraether lipids in Carminowe Creek catchment (southwest England), PANGAEA, https://doi.org/10.1594/PANGAEA.918523, 2020.

Harvey, H. R., Fallon, R. D., and Patton, J. S.: The effect of organic matter and oxygen on the degradation of bacterial membrane lipids in marine sediments, Geochim. Cosmochim. Ac., 50, 795-804, https://doi.org/10.1016/0016-7037(86)90355-8, 1986.

Hedges, J. I., Clark, W. A., Quay, P. D., Richey, J. E., Devol, A. H., and Santos, M.: Compositions and fluxes of particulate organic material in the Amazon River, Limnol. Oceanogr., 31, 717-738, https://doi.org/10.4319/lo.1986.31.4.0717, 1986.

Hedges, J. I., Keil, R. G., and Benner, R.: What happens to terrestrial organic matter in the ocean?, Org. Geochem., 27, 195-212, https://doi.org/10.1016/S0146-6380(97)00066-1, 1997.

Hedges, J. I., Mayorga, E., Tsamakis, E., McClain, M. E., Aufdenkampe, A., Quay, P., Richey, J. E., Benner, R., Opsahl, S., Black, B., Pimentel, T., Quintanilla, J., and Maurice, L.: Organic matter in Bolivian tributaries of the Amazon River: A comparison to the lower mainstream, Limnol. Oceanogr., 45, 1449-1466, https://doi.org/10.4319/lo.2000.45.7.1449, 2000.

Hemingway, J. D., Schefuß, E., Spencer, R. G. M., Dinga, B. J., Eglinton, T. I., McIntyre, C., and Galy, V. V.: Hydrologic controls on seasonal and inter-annual variability of Congo River particulate organic matter source and reservoir age, Chem. Geol., 466, 454-465, https://doi.org/10.1016/j.chemgeo.2017.06.034, 2017.

Hopmans, E. C., Weijers, J. W. H., Schefuß, E., Herfort, L., Sinninghe Damsté, J. S., and Schouten, S.: A novel proxy for terrestrial organic matter in sediments based on branched and isoprenoid tetraether lipids, Earth Planet. Sc. Lett., 224, 107-116, https://doi.org/10.1016/j.epsl.2004.05.012, 2004.

Hopmans, E. C., Schouten, S., and Sinninghe Damsté, J. S.: The effect of improved chromatography on GDGT-based palaeoproxies, Org. Geochem., 93, 1-6, https://doi.org/10.1016/j.orggeochem.2015.12.006, 2016.

Huguet, A., Meador, T. B., Laggoun-Défarge, F., Könneke, M., Wu, W., Derenne, S., and Hinrichs, K. U.: Production rates of bacterial tetraether lipids and fatty acids in peatland under varying oxygen concentrations, Geochim. Cosmochim. Ac., 203, 103116, https://doi.org/10.1016/j.gca.2017.01.012, 2017.

Huguet, C., Hopmans, E. C., Febo-Ayala, W., Thompson, D. H., Sinninghe Damsté, J. S., and Schouten, S.: An improved method to determine the absolute abundance of glycerol dibiphytanyl glycerol tetraether lipids, Org. Geochem., 37, 1036-1041, https://doi.org/10.1016/j.orggeochem.2006.05.008, 2006.

Inglis, G. N., Collinson, M. E., Riegel, W., Wilde, V., Farnsworth, A., Lunt, D. J., Valdes, P., Robson, B. E., Scott, A. C., Lenz, O. K., Naafs, B. D. A., and Pancost, R. D.: Midlatitude continental temperatures through the early Eocene in western Europe, Earth Planet. Sc. Lett., 460, 86-96, https://doi.org/10.1016/j.epsl.2016.12.009, 2017.

Jaeschke, A., Rethemeyer, J., Lappé, M., Schouten, S., Boeckx, P., and Schefuß, E.: Influence of land use on distribution of soil nalkane $\delta \mathrm{D}$ and brGDGTs along an altitudinal transect in Ethiopia: Implications for (paleo)environmental studies, Org. Geochem., 124, 77-87, https://doi.org/10.1016/j.orggeochem.2018.06.006, 2018. 
Janzen, H. H.: Carbon cycling in earth systems - A soil science perspective, Agr. Ecosyst. Environ., 104, 399-417, https://doi.org/10.1016/j.agee.2004.01.040, 2004.

Kim, J. H., Zell, C., Moreira-Turcq, P., Pérez, M. A. P., Abril, G., Mortillaro, J. M., Weijers, J. W. H., Meziane, T., and Sinninghe Damsté, J. S.: Tracing soil organic carbon in the lower Amazon River and its tributaries using GDGT distributions and bulk organic matter properties, Geochim. Cosmochim. Ac., 90, 163180, https://doi.org/10.1016/j.gca.2012.05.014, 2012.

Kim, J. H., Ludwig, W., Buscail, R., Dorhout, D., and Sinninghe Damsté, J. S.: Tracing tetraether lipids from source to sink in the Rhône river system (NW Mediterranean), Front. Earth Sci., 3, 22, https://doi.org/10.3389/feart.2015.00022, 2015.

Liang, J., Russell, J. M., Xie, H., Lupien, R. L., Si, G., Wang, J., Hou, J., and Zhang, G.: Vegetation effects on temperature calibrations of branched glycerol dialkyl glycerol tetraether (brGDGTs) in soils, Org. Geochem., 127, 1-11, https://doi.org/10.1016/j.orggeochem.2018.10.010, 2019.

Loomis, S. E., Russell, J. M., and Sinninghe Damsté, J. S.: Distributions of branched GDGTs in soils and lake sediments from western Uganda: Implications for a lacustrine paleothermometer, Org. Geochem., 42, 739-751, https://doi.org/10.1016/j.orggeochem.2011.06.004, 2011.

Loomis, S. E., Russell, J. M., Heureux, A. M., D’Andrea, W. J., and Sinninghe Damsté, J. S.: Seasonal variability of branched glycerol dialkyl glycerol tetraethers (brGDGTs) in a temperate lake system, Geochim. Cosmochim. Ac., 144, 173-187, https://doi.org/10.1016/j.gca.2014.08.027, 2014.

Menges, J., Huguet, C., Alcañiz, J. M., Fietz, S., Sachse, D., and Rosell-Melé, A.: Influence of water availability in the distributions of branched glycerol dialkyl glycerol tetraether in soils of the Iberian Peninsula, Biogeosciences, 11, 2571-2581, https://doi.org/10.5194/bg-11-2571-2014, 2014.

Ménot, G., Bard, E., Rostek, F., Weijers, J. W. H., Hopmans, E. C., Schouten, S., and Sinninghe Damsté, J. S.: Early Reactivation of European Rivers During the Last Deglaciation, Science, 313, 1623-1625, 2006.

Miller, D. R., Habicht, M. H., Keisling, B. A., Castañeda, I. S., and Bradley, R. S.: A 900-year New England temperature reconstruction from in situ seasonally produced branched glycerol dialkyl glycerol tetraethers (brGDGTs), Clim. Past, 14, 16531667, https://doi.org/10.5194/cp-14-1653-2018, 2018.

Mueller-Niggemann, C., Utami, S. R., Marxen, A., Mangelsdorf, K., Bauersachs, T., and Schwark, L.: Distribution of tetraether lipids in agricultural soils - differentiation between paddy and upland management, Biogeosciences, 13, 1647-1666, https://doi.org/10.5194/bg-13-1647-2016, 2016.

Naafs, B. D. A., Inglis, G. N., Zheng, Y., Amesbury, M. J., Biester, H., Bindler, R., Blewett, J., Burrows, M. A., del Castillo Torres, D., Chambers, F. M., Cohen, A. D., Evershed, R. P., Feakins, S. J., Gałka, M., Gallego-Sala, A., Gandois, L., Gray, D. M., Hatcher, P. G., Honorio Coronado, E. N., Hughes, P. D. M., Huguet, A., Könönen, M., LaggounDéfarge, F., Lähteenoja, O., Lamentowicz, M., Marchant, R., McClymont, E., Pontevedra-Pombal, X., Ponton, C., Pourmand, A., Rizzuti, A. M., Rochefort, L., Schellekens, J., De Vleeschouwer, F., and Pancost, R. D.: Introducing global peatspecific temperature and $\mathrm{pH}$ calibrations based on brGDGT bacterial lipids, Geochim. Cosmochim. Ac., 208, 285-301, https://doi.org/10.1016/j.gca.2017.01.038, 2017.

Naeher, S., Peterse, F., Smittenberg, R. H., Niemann, H., Zigah, P. K., and Schubert, C. J.: Sources of glycerol dialkyl glycerol tetraethers (GDGTs) in catchment soils, water column and sediments of Lake Rotsee (Switzerland) - Implications for the application of GDGT-based proxies for lakes, Org. Geochem., 66, 164-173, https://doi.org/10.1016/j.orggeochem.2013.10.017, 2014.

O'Sullivan, P. E.: The eutrophication of shallow coastal lakes in Southwest England - understanding and recommendations for restoration, based on palaeolimnology, historical records, and the modelling of changing phosphorus loads, Hydrobiologia, 243, 421-434, https://doi.org/10.1007/BF00007059, 1992.

Peterse, F., Kim, J. H., Schouten, S., Kristensen, D. K., Koç, N., and Sinninghe Damsté, J. S.: Constraints on the application of the MBT/CBT palaeothermometer at high latitude environments (Svalbard, Norway), Org. Geochem., 40, 692-699, https://doi.org/10.1016/j.orggeochem.2009.03.004, 2009.

Peterse, F., Nicol, G. W., Schouten, S., and Sinninghe Damsté, J. S.: Influence of soil $\mathrm{pH}$ on the abundance and distribution of core and intact polar lipid-derived branched GDGTs in soil, Org. Geochem., 41, 1171-1175, https://doi.org/10.1016/j.orggeochem.2010.07.004, 2010.

Peterse, F., Prins, M. A., Beets, C. J., Troelstra, S. R., Zheng, H., Gu, Z., Schouten, S., and Damsté, J. S. S.: Decoupled warming and monsoon precipitation in East Asia over the last deglaciation, Earth Planet. Sc. Lett., 301, 256-264, https://doi.org/10.1016/j.eps1.2010.11.010, 2011.

Peterse, F., van der Meer, J., Schouten, S., Weijers, J. W. H., Fierer, N., Jackson, R. B., Kim, J. H., and Sinninghe Damsté, J. S.: Revised calibration of the MBT-CBT paleotemperature proxy based on branched tetraether membrane lipids in surface soils, Geochim. Cosmochim. Ac., 96, 215-229, https://doi.org/10.1016/j.gca.2012.08.011, 2012.

Powers, L. A., Werne, J. P., Johnson, T. C., Hopmans, E. C., Sinninghe Damsté, J. S., and Schouten, S.: Crenarchaeotal membrane lipids in lake sediments: A new paleotemperature proxy continental paleoclimate reconstruction?, Geology, 32, 613-616, https://doi.org/10.1130/G20434.1, 2004.

R Core Team: R: A language and environment for statistical computing, R Foundation for Statistical Computing, Vienna, Austria, available at: http://www.R-project.org, last access: April 2018.

Russell, J. M., Hopmans, E. C., Loomis, S. E., Liang, J., and Sinninghe Damsté, J. S.: Distributions of 5- and 6-methyl branched glycerol dialkyl glycerol tetraethers (brGDGTs) in East African lake sediment: Effects of temperature, $\mathrm{pH}$, and new lacustrine paleotemperature calibrations, Org. Geochem., 117, 56-69, https://doi.org/10.1016/j.orggeochem.2017.12.003, 2018.

Schoon, P. L., De Kluijver, A., Middelburg, J. J., Downing, J. A., Sinninghe Damsté, J. S., and Schouten, S.: Influence of lake water $\mathrm{pH}$ and alkalinity on the distribution of core and intact polar branched glycerol dialkyl glycerol tetraethers (GDGTs) in lakes, Org. Geochem., 60, 72-82, https://doi.org/10.1016/j.orggeochem.2013.04.015, 2013.

Schouten, S., Hopmans, E. C., Pancost, R. D., and Sinninghe Damsté, J. S.: Widespread occurrence of structurally diverse tetraether membrane lipids: Evidence for the ubiquitous presence of low-temperature relatives of hyper- 
thermophiles, P. Natl. Acad. Sci. USA, 97, 14421-14426, https://doi.org/10.1073/pnas.97.26.14421, 2000.

Sinninghe Damsté, J. S.: Spatial heterogeneity of sources of branched tetraethers in shelf systems: The geochemistry of tetraethers in the Berau River delta (Kalimantan, Indonesia), Geochim. Cosmochim. Ac., 186, 13-31, https://doi.org/10.1016/j.gca.2016.04.033, 2016.

Sinninghe Damsté, J. S., Schouten, S., Hopmans, E. C., van Duin, A. C. T., and Geenevasen, J. A. J.: Crenarchaeol, J. Lipid Res., 43, 1641-1651, https://doi.org/10.1194/jlr.M200148JLR200, 2002.

Sinninghe Damsté, J. S., Ossebaar, J., Abbas, B., Schouten, S., and Verschuren, D.: Fluxes and distribution of tetraether lipids in an equatorial African lake: Constraints on the application of the TEX86 palaeothermometer and BIT index in lacustrine settings, Geochim. Cosmochim. Ac., 73, 4232-4249, https://doi.org/10.1016/j.gca.2009.04.022, 2009.

Sinninghe Damsté, J. S., Rijpstra, W. I. C., Hopmans, E. C., Weijers, J. W. H., Foesel, B. U., Overmann, J., and Dedysh, S. N.: 13,16-Dimethyl octacosanedioic acid (iso-Diabolic Acid), a common membrane-spanning lipid of Acidobacteria subdivisions 1 and 3, Appl. Environ. Microb., 77, 4147-4154, https://doi.org/10.1128/AEM.00466-11, 2011.

Sinninghe Damsté, J. S., Rijpstra, W. I. C., Hopmans, E. C., Foesel, B. U., Wüst, P. K., Overmann, J., Tank, M., Bryant, D. A., Dunfield, P. F., Houghton, K., and Stott, M. B.: Ether- and ester-bound iso-diabolic acid and other lipids in members of Acidobacteria subdivision 4, Appl. Environ. Microb., 80, 52075218, https://doi.org/10.1128/AEM.01066-14, 2014.

Sinninghe Damsté, J. S., Rijpstra, W. I. C., Foesel, B. U., Huber, K. J., Overmann, J., Nakagawa, S., Kim, J. J., Dunfield, P. F., Dedysh, S. N., and Villanueva, L.: An overview of the occurrence of ether- and ester-linked iso-diabolic acid membrane lipids in microbial cultures of the Acidobacteria: Implications for brGDGT paleoproxies for temperature and $\mathrm{pH}$, Org. Geochem., 124, 63-76, https://doi.org/10.1016/j.orggeochem.2018.07.006, 2018.

Smith, P.: Land use change and soil organic carbon dynamics, Nutr. Cycl. Agroecosys., 81, 169-178, https://doi.org/10.1007/s10705-007-9138-y, 2008.

Steenwerth, K. L., Jackson, L. E., Calderón, F. J., Stromberg, M. R., and Scow, K. M.: Erratum to "Soil community composition and land use history in cultivated and grassland ecosystems of coastal California" [Soil Biology \& Biochemistry 34(11) 1599-1611], Soil Biol. Biochem., 35, 487-500, https://doi.org/10.1016/S0038-0717(03)00027-0, 2003.

Tierney, J. E. and Russell, J. M.: Distributions of branched GDGTs in a tropical lake system: Implications for lacustrine application of the MBT/CBT paleoproxy, Org. Geochem., 40, 1032-1036, https://doi.org/10.1016/j.orggeochem.2009.04.014, 2009.

Tierney, J. E., Russell, J. M., Eggermont, H., Hopmans, E. C., Verschuren, D., and Sinninghe Damsté, J. S.: Environmental controls on branched tetraether lipid distributions in tropical East African lake sediments, Geochim. Cosmochim. Ac., 74, 49024918, https://doi.org/10.1016/j.gca.2010.06.002, 2010.

Wakeham, S. G. and Lee, C.: Organic Geochemistry, edited by: Engel, M. H. and Macko, S. A., Springer US, Boston, MA, 1993.

Wang, H., Liu, W., Zhang, C. L., Liu, Z., and He, Y.: Branched and isoprenoid tetraether (BIT) index traces water content along two marsh-soil transects surrounding Lake Qinghai: Implications for paleo-humidity variation, Org. Geochem., 59, 75-81, https://doi.org/10.1016/j.orggeochem.2013.03.011, 2013.

Weber, Y., De Jonge, C., Rijpstra, W. I. C., Hopmans, E. C., Stadnitskaia, A., Schubert, C. J., Lehmann, M. F., Sinninghe Damsté, J. S., and Niemann, H.: Identification and carbon isotope composition of a novel branched GDGT isomer in lake sediments: Evidence for lacustrine branched GDGT production, Geochim. Cosmochim. Ac., 154, 118-129, https://doi.org/10.1016/j.gca.2015.01.032, 2015.

Weber, Y., Sinninghe Damsté, J. S., Zopfi, J., De Jonge, C., Gilli, A., Schubert, C. J., Lepori, F., Lehmann, M. F., and Niemann, H.: Redox-dependent niche differentiation provides evidence for multiple bacterial sources of glycerol tetraether lipids in lakes, P. Natl. Acad. Sci. USA, 115, 10926-10931, https://doi.org/10.1073/pnas.1805186115, 2018.

Weijers, J. W. H., Schouten, S., Hopmans, E. C., Geenevasen, J. A. J., David, O. R. P., Coleman, J. M., Pancost, R. D., and Sinninghe Damste, J. S.: Membrane lipids of mesophilic anaerobic bacteria thriving in peats have typical archaeal traits, Environ. Microbiol., 8, 648-657, https://doi.org/10.1111/j.1462-2920.2005.00941.x, 2006 .

Weijers, J. W. H., Schouten, S., Spaargaren, O. C., and Sinninghe Damsté, J. S.: Occurrence and distribution of tetraether membrane lipids in soils: Implications for the use of the TEX86 proxy and the BIT index, Org. Geochem., 37, 1680-1693, https://doi.org/10.1016/j.orggeochem.2006.07.018, 2006b.

Weijers, J. W. H., Schouten, S., van den Donker, J. C., Hopmans, E. C., and Sinninghe Damsté, J. S.: Environmental controls on bacterial tetraether membrane lipid distribution in soils, Geochim. Cosmochim. Ac., 71, 703-713, https://doi.org/10.1016/j.gca.2006.10.003, 2007a.

Weijers, J. W. H., Schefuß, E., Schouten, S., and Sinninghe Damsté, J. S.: Evolution of Tropical Africa over the Last Deglaciation, Science, 8247, 5-8, 2007b.

Weijers, J. W. H., Wiesenberg, G. L. B., Bol, R., Hopmans, E. C., and Pancost, R. D.: Carbon isotopic composition of branched tetraether membrane lipids in soils suggest a rapid turnover and a heterotrophic life style of their source organism(s), Biogeosciences, 7, 2959-2973, https://doi.org/10.5194/bg-7-29592010, 2010.

Weijers, J. W. H., Bernhardt, B., Peterse, F., Werne, J. P., Dungait, J. A. J., Schouten, S., and Sinninghe Damsté, J. S.: Absence of seasonal patterns in MBT-CBT indices in midlatitude soils, Geochim. Cosmochim. Ac., 75, 3179-3190, https://doi.org/10.1016/j.gca.2011.03.015, 2011.

Zell, C., Kim, J. H., Moreira-Turcq, P., Abril, G., Hopmans, E. C., Bonnet, M. P., Sobrinho, R. L., and Sinninghe Damsté, J. S.: Disentangling the origins of branched tetraether lipids and crenarchaeol in the lower Amazon river: Implications for GDGT-based proxies, Limnol. Oceanogr., 58, 343-353, https://doi.org/10.4319/lo.2013.58.1.0343, 2013.

Zell, C., Kim, J. H., Hollander, D., Lorenzoni, L., Baker, P., Silva, C. G., Nittrouer, C., and Sinninghe Damsté, J. S.: Sources and distributions of branched and isoprenoid tetraether lipids on the Amazon shelf and fan: Implications for the use of GDGT-based proxies in marine sediments, Geochim. Cosmochim. Ac., 139, 293-312, https://doi.org/10.1016/j.gca.2014.04.038, 2014. 
Zhang, C. L., Wang, J., Wei, Y., Zhu, C., Huang, L., and Dong, H.: Production of branched tetraether lipids in the lower Pearl River and estuary: Effects of extraction methods and impact on bGDGT proxies, Front. Microbiol., 2, 1-18, https://doi.org/10.3389/fmicb.2011.00274, 2012.
Zheng, Y., Pancost, R. D., Liu, X., Wang, Z., Naafs, B. D. A., Xie, X., Liu, Z., Yu, X., and Yang, H.: Atmospheric connections with the North Atlantic enhanced the deglacial warming in northeast China, Geology, 45, 1031-1034, https://doi.org/10.1130/G39401.1, 2017. 